\title{
Convolvulaceae do Parque Nacional do Catimbau, Pernambuco, Brasil ${ }^{1}$
} Convolvulaceae of National Park Catimbau, Pernambuco, Brazil

\author{
Geadelande Carolino Delgado Júnior ${ }^{2}$, Maria Teresa Buril ${ }^{3} \&$ Marccus Alves $^{3}$
}

\begin{abstract}
Resumo
Convolvulaceae é constituída por 58 gêneros e ca. 1880 espécies com distribuição cosmopolita, sendo mais frequente nos trópicos. No Brasil é representada por 19 gêneros e aproximadamente 370 espécies. Em levantamentos florísticos na Caatinga, Convolvulaceae aparece como uma das famílias com maior riqueza de espécies. Esse estudo tem como objetivo realizar o tratamento taxonômico das Convolvulaceae do Parque Nacional do Catimbau-PE. Foram encontradas 30 espécies e cinco gêneros: Ipomoea, Jacquemontia, Evolvulus, Merremia e Turbina. São apresentados chave de identificação, descrições e comentários sobre as espécies, além de ilustrações de caracteres diagnósticos.
\end{abstract}

Palavras-chave: Caatinga, Ipomoea, florística, taxonomia, trepadeiras.

\begin{abstract}
Convolvulaceae is a cosmopolitan family with 58 genera and ca. 1880 species, being more frequent in the tropics. In Brazil, there are 19 genera and approximately 370 species. Convolvulaceae is one of the richest families appearing in some floristic composition studies held in Caatinga biome. This study aimed to treat the Convolvulaceae species from Parque Nacional do Catimbau, located in Brazilian northeastern semiarid, where 30 species and five genera were found: Ipomoea, Jacquemontia, Evolvulus, Merremia and Turbina. Identification key, descriptions and comments on the species and illustrations of some diagnostic characters are presented.
\end{abstract}

Key words: Caatinga, climbing plants, floristic, Ipomoea, taxonomy.

\section{Introdução}

Convolvulaceae compreende 58 gêneros e cerca de 1.880 espécies (Staples 2012) e apresenta distribuição cosmopolita, sendo mais comum nos trópicos (Staples \& Brummitt 2007). A família está inserida na ordem Solanales e é claramente monofilética (Stefanovic et al. 2002). Entretanto, é por vezes considerada como de taxonomia difícil quanto à delimitação genérica e específica (Robertson 1982), devido à plasticidade dos caracteres morfológicos.

São caracterizadas como ervas, arbustos, árvores, trepadeiras ou holoparasitas (Cuscuta L.), com látex ocasionalmente presente, folhas alternas, simples ou raramente compostas, sem estípulas. A inflorescência é cimosa e às vezes reduzida a uma única flor que é dialissépala a raramente gamossépala, gamopétala, plicada, rotácea, campanulada, hipocrateriforme ou infundibuliforme, com nervura mesopétala geralmente proeminente, estames (5) epipétalos, ovário súpero e fruto capsular (Austin 2004).

No Brasil são reconhecidos 19 gêneros e cerca de 370 espécies, sendo Ipomoea L., Evolvulus L. e Jacquemontia Choisy os mais representativos. Para a Caatinga estão registrados 10 gêneros e cerca de 110 espécies (Bianchini \& Ferreira 2013; Buril 2013). Apesar de Convolvulaceae figurar entre as famílias com maior riqueza de espécies na Caatinga (e.g. Barbosa et al. 2007; Vital 2009; SiqueiraFilho et al. 2012), os trabalhos de cunho florísticotaxonômicos com enfoque na família neste bioma ainda são escassos. Para outras regiões, entretanto, a diversidade da família tem sido mais amplamente estudada, como a Região Norte (e.g. Austin \& Cavalcante 1982), Centro-Oeste (Bianchini 2001), Sudeste (Bianchini \& Pirani 1997; Moura 2010; Bianchini 1998) e Sul (Ferreira \& Miotto 2009; Ferreira \& Mioto 2013).

\footnotetext{
${ }^{1}$ Parte da dissertação de Mestrado do primeiro autor.

${ }^{2}$ Universidade Federal de Pernambuco, Depto. Botânica, Programa de Pós-graduação em Biologia Vegetal, Av. Professor Moraes Rego s/n, 50670-901, Recife, PE, Brasil.

${ }^{3}$ Universidade Federal de Pernambuco, Depto. Botânica, Lab. Morfo-taxonomia Vegetal,Av. Professor Moraes Rego s/n, 50670-901, Recife, PE, Brasil. Autor para correspondência: geadelande@gmail.com
} 
Desta forma, este trabalho tem como objetivo, apresentar a diversidade taxonômica de Convolvulaceae ocorrente em uma das poucas Unidades de Conservação existentes na Caatinga, o Parque Nacional do Catimbau, ampliando assim o conhecimento da família para esse Domínio Fitogeográfico e fornecendo subsídios que contribuam para conservação da área.

\section{Material e Métodos}

O Parque Nacional do Catimbau (PARNA Catimbau), que compreende uma área total de cerca de $607 \mathrm{~km}^{2}$, localiza-se nos municípios de Buíque, Ibimirim e Tupanantiga, a aproximadamente 280 $\mathrm{km}$ de Recife, entre as coordenadas $8^{\circ} 24^{\prime}-8^{\circ} 36^{\prime} \mathrm{S}$ e $37^{\circ} 09^{\prime}-37^{\circ} 14^{\prime} \mathrm{W}$ (Melo 2012). O clima é semiárido tropical com temperaturas médias anuais de $23,7^{\circ} \mathrm{C}$ e precipitação média $706 \mathrm{~mm}$ ao ano, sendo o mês de maio o mais chuvoso e novembro o mais seco (SADMET/INMET 2013).

O PARNA Catimbau foi criado em 2002 sendo considerado uma área de "Extrema Importância Biológica e Prioritária para Conservação da Caatinga" por apresentar números relevantes de endemismos (e.g. Mandevilla catimbauensis Souza-Silva, Rapini \& J.F. Morales - Apocynaceae; Tillandsia catimbauensis Leme, W. Till \& J.A. Siqueira - Bromeliaceae) e espécies raras da fauna e flora (Sampaio et al. 2002). Apresenta vegetação heterogênea, com ao menos quatro fitofisionomias, de acordo com Rodal et al. (1998), a saber: campos rupestres, caatinga arbustiva, vegetação florestal perenifólia e a vegetação arbustiva perenifólia.

Os dados apresentados estão baseados nas amostras obtidas em expedições de coleta, as quais se concentraram no município de Buíque, de abril/2012 a setembro/2013, além daquelas depositadas nos herbários HST, HUEFS, HVASF, IPA, JPB, PEUFR e UFP. As amostras botânicas foram submetidas às técnicas usuais em taxonomia vegetal (Mori et al. 1985) e depositadas no Herbário UFP, com duplicatas enviadas a herbários nacionais de relevância para a Caatinga.

A identidade dos táxons foi estabelecida com base em bibliografia especializada (Meissner 1869; Ooststroom 1934; O’Donell 1941; Austin
\& Staples 1991; Bianchini 1998; Junqueira \& Bianchini 2006; Vital 2009; Buril 2013), amostras previamente identificadas por especialistas e análise de materiais-tipo. A nomenclatura morfológica adotada segue Harris \& Harris (2000) e Stearn (2004).

As espécies foram classificadas em três categorias (adaptado Durigon et al. 2009), de acordo com sua ocorrência visual na área de estudo: rara, quando encontrados de um a três indivíduos e/ou populações localizadas em apenas uma localidade do PARNA; ocasional, quando encontrados de 4 a 10 indivíduos por espécie e em mais de uma localidade no PARNA e abundante, quando registrados mais de 10 indivíduos e populações distribuídas em várias áreas do PARNA.

\section{Resultados e Discussão}

Convolvulaceae está representada na área por 30 espécies e cinco gêneros, sendo Ipomoea o mais representativo com 16 espécies, seguido de Jacquemontia (7 spp.), Evolvulus (4 spp.), Merremia Dennst. (2 spp.) e Turbina Raf. com apenas uma espécie. Os resultados demonstram um incremento em 18 espécies ao reportado por Vital et al. (2008).

De maneira geral, as espécies são amplamente distribuídas, no entanto, destaca-se Jacquemontia chysanthera Buril, recém-descrita e até então conhecida para poucas localidades nos estados da Bahia e Pernambuco, tendo sido classificada como vulnerável (Buril \& Alves 2011). Além disto, foram reconhecidas espécies endêmicas da Caatinga como Evolvulus daphnoides Moric., Ipomoea marcellia Meisn., I. pintoi O'Donell e I. rosea Choisy.

Os dados encontrados reforçam a relevância da diversidade vegetal do PARNA Catimbau e apontaram que 33\% das espécies de Convolvulaceae são raras e foram encontradas principalmente em áreas antropizadas, desta forma há necessidade de medidas mais eficazes de conservação, visto que a área sofre com ações contínuas de devastação devido à agricultura de subsistência, pastagem, cultura extensiva e especulação imobiliária. 
Chave de identificação das espécies de Convolvulaceae ocorrentes no Parque Nacional do Catimbau

1. Folhas compostas.

2. Folíolos com margem denteada

29. Merremia cissoides

2'. Folíolos com margem inteira.

3. Lâminas foliares e pecíolos glabros; sépalas iguais entre si, glabras

15. Ipomoea rosea

3'. Lâminas foliares pubescentes e pecíolos hirsutos; sépalas desiguais entre si, densamente hirsutas 28. Merremia aegyptia

1'. Folhas simples.

4. Plantas trepadeiras.

5. Ramos e/ou lâminas foliares com tricomas estrelados.

6. Ramos com tricomas glandulares

21. Jacquemontia agrestis

6'. Ramos sem tricomas glandulares.

7. Tricomas 5(-7)-armados; anteras amarelas

22. Jacquemontia chysanthera

7'. Tricomas 3-armados; anteras brancas.

8. Inflorescência com bractéolas iguais ou maiores que as sépalas externas.

9. Ramos densamente pubescentes; bractéolas lineares

24. Jacquemontia ferruginea var. ambigua

9'. Ramos glabrescentes a velutinos; bractéolas lanceoladas ou oblanceoladas

27. Jacquemontia pentanthos

8'. Inflorescência com bractéolas menores que as sépalas externas.

10. Sépalas desiguais entre si, as externas elípticas a lanceoladas, pubescentes; corola azul 23. Jacquemontia corymbulosa

10'. Sépalas subiguais entre si, rotundas, glabrescentes a pubescentes; corola branca com fauce vinácea 26. Jacquemontia nodiflora

5'. Ramos e/ou lâmina foliar glabros ou com tricomas simples.

11. Ramos glabros a glabrescentes.

12. Folhas elípticas a oblanceoladas; pecíolo e pedicelo com nectários; sépalas iguais ou subiguais entre si 13. Ipomoea pintoi

12'. Folhas cordadas a sagitadas, cordadas ou sagitadas; pecíolo e pedicelo sem nectários; sépalas desiguais entre si.

13. Sépalas externas com rostro subapical.

14. Rostro subapical $\leq 1 \mathrm{~mm}$ compr.; corola infundibuliforme, roxa 6. Ipomoea bahiensis

14'. Rostro subapical > 2,5 mm compr.; corola hipocrateriforme, vermelha ..

13'. Sépalas externas sem rostro subapical.

9. Ipomoea hederifolia

15. Ápice foliar acuminado, não mucronado; sépalas não mucronadas

15'. Ápice foliar agudo, mucronado; sépalas mucronadas.

17. Ipomoea subalata

16. Face da lâmina foliar adaxial glabra; pecíolo glabro; sépalas com margem não ciliada 14. Ipomoea piurensis

16'. Face da lâmina foliar adaxial pilosa; pecíolo pubescente; sépalas com margem ciliada 20. Ipomoea af. vestalli

11'. Ramos vilosos, lanosos, hirsutos ou esparsamente pubescentes.

17. Ramos hirsutos ou esparsamente pubescentes.

18. Folhas com margens ciliadas e ápice mucronado.

19. Folhas trilobadas ou inteiras; sépalas externas glabras, com ápice agudo, mucronado e margem ciliada; corola inteiramente rosa

19. Ipomoea triloba 
19’. Folhas 5-lobadas; sépalas externas glabrescentes, com ápice apiculado, não mucronado, margem não ciliada; corola amarela com fauce vinácea ...... 10. Ipomoea longeramosa

18'. Folhas com margem não ciliada, não mucronadas.

20. Folhas esparsamente hirsutas; sépalas iguais, ápice caudado, densamente hirsutas........

12. Ipomoea nil

20’. Folhas glabras; sépalas subiguais, ápice agudo e mucronado, glabras

16. Ipomoea setosa

17'. Ramos vilosos ou lanosos.

21. Folhas com margem serreadas; corola campanulada

25. Jacquemontia montana

21'. Folhas com margem inteira; corola infundibuliforme.

22. Corola branco-amarelada

11. Ipomoea marcellia

22'. Corola rosa.

23. Sépalas externas levemente maiores que as internas; sépalas externas glabras a glabrescentes 7. Ipomoea brasiliana

23'. Sépalas externas menores que as internas; sépalas externas pubescentes ou vilosas.

24. Folhas com a face adaxial glabrescente; sépalas externas e internas pubescentes; nervura mesopétala vilosa; fruto indeiscente 30. Turbina cordata

24'. Folhas com face adaxial densamente vilosa; sépalas externas vilosas e internas glabras a glabrescentes; nervura mesopétala glabra; fruto deiscente

18. Ipomoea subincana

4'. Ervas, subarbustos ou arbustos eretos ou prostrados.

25. Folhas sésseis ou com pecíolo $\leq 1 \mathrm{~mm}$ compr.

26. Inflorescência em glomérulos congestos ou alongados, terminais ou axilares, bractéolas conspícuas 4. Evolvulus glomeratus

26'. Inflorescência em monocásios ou flores solitárias, sempre axilares, bractéolas inconspícuas ou ausentes.

27. Ramos densamente vilosos; folhas oblíquas a ovais; sépalas lanceoladas 3. Evolvulus frankenioides

27'. Ramos glabrescentes a seríceos; folhas oblongas, oblanceoladas, lineares a lanceoladas; sépalas rotundas, ovais a elípticas.

28. Folhas oblongas a oblanceoladas; sépalas com ápice obtuso, margem ciliada, glabrescentes 1. Evolvulus daphnoides

28'. Folhas lineares a lanceoladas; sépalas com ápice acuminado, margem não ciliadas, seríceas 2. Evolvulus elegans

$25^{\prime}$. Folhas com pecíolos $\geq 5 \mathrm{~mm}$ compr..

29. Subarbustos prostrados; folhas reniformes a deltoides

5. Ipomoea asarifolia

29'. Arbustos eretos; folhas lanceoladas

8. Ipomoea carnea subsp. fistulosa

Evolvulus L., Sp. pl. ed. 2: 391. 1762.

Ervas ou subarbustos, eretos ou prostrados; látex ausente; tricomas simples. Folhas simples, inteiras, margem inteira, sésseis ou pecioladas. Inflorescência axilar ou terminal; bractéolas presentes ou ausentes. Sépalas iguais ou subiguais; corola lobada, azul, tricomas distribuídos na região da mesopétala; estames 5, inclusos, glabros, anteras oblongas; ovário globoso, bilocular, 2 óvulos por lóculos, glabro, estiletes 2, cada um com dois estigmas; estigmas lineares. Fruto cápsula, deiscente; sementes 4 .
1. Evolvulus daphnoides Moric., Pl. Nouv. Am.: 59. 1839.

Fig. 1a-b

Subarbustos eretos. Ramos glabrescentes a seríceos. Folhas $0,8-2 \times 0,2-0,6 \mathrm{~cm}$, cartáceas, seríceas em ambas as faces, oblongas a oblanceoladas, ápice arredondado, base cuneada, não discolores; pecíolo até $0,5 \mathrm{~mm}$ compr.. Flores solitárias ou em monocásios com até 3 flores, axilares, pedúnculo ausente; bractéolas ausentes; pedicelo 4-5 $\mathrm{mm}$ compr.; sépalas iguais entre si, ca. $2,5 \times 2 \mathrm{~mm}$, glabrescentes, ovais a rotundas, ápice obtuso e ciliado, base arredondada; corola 


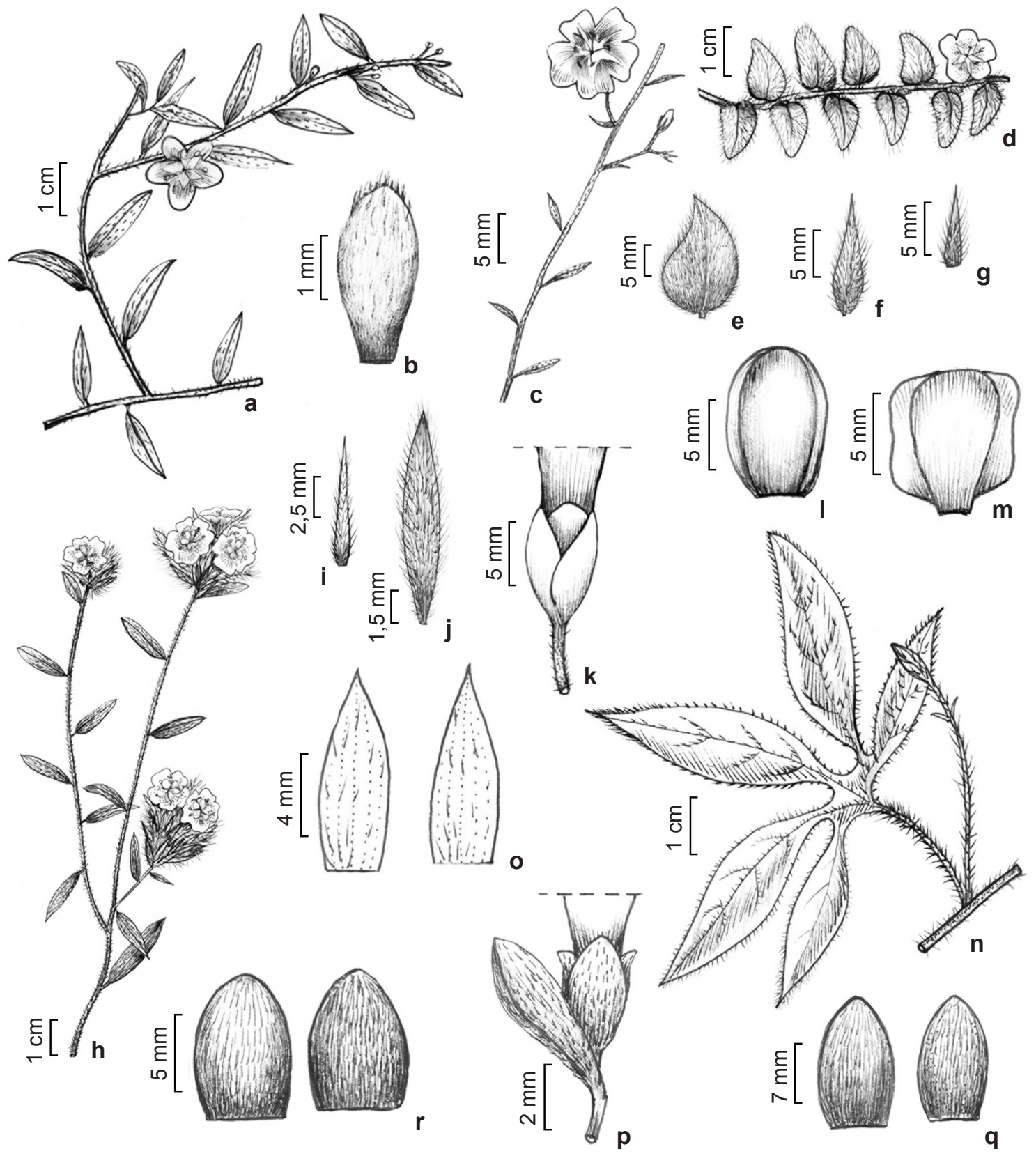

Figura 1 - a-b. Evolvulus daphnoides (M.T Vital.et al. 21) - a. ramo florífero; b. sépala. c. Evolvulus elegans (G.C. Delgado-Junior 643) - ramo florífero. d-g. Evolvulus frankenioides (G.C. Delgado-Junior 594) - d. ramo florífero; e. folha; f. sépala externa; g. bractéolas. h-j. Evolvulus glomeratus (G.C. Delgado-Junior 663) - h. ramo florífero; i. sépala; j. bractéola. k-m. Ipomoea brasiliana (G.C. Delgado-Junior 453) - k. cálice, vista lateral; 1. sépala externa; $\mathrm{m}$. sépala interna. n-o. Ipomoea longeramosa (R. Pereira 2706) - n. ramo fértil; o. sépala externa (esquerda), sépala interna (direita). p-r. Ipomoea marcellia (R. Pereira 2725) - p. cálice e bractéola, vista lateral; q. sépalas externas; r. sépalas internas.

Figure 1 - a-b. Evolvulus daphnoides (M.T. Vital et al. 21) - a. fertile branch; b. sepal. c. Evolvulus elegans (G.C. Delgado-Junior 643) - fertile branch. d-g. Evolvulus frankenioides (G.C. Delgado-Junior 594) - d. fertile branch; e. leaf; f. outer sepal; g. bracteoles;. h-i. Evolvulus glomeratus (G.C. Delgado-Junior 663) - h. fertile branch; i. sepal; j. bracteoles. k-m. Ipomoea brasiliana (G.C. Delgado-Junior $453)$ - k. calyx, lateral view; 1. outer sepal; m. inner sepal. n-o. Ipomoea longeramosa (R. Pereira 2706) - n. fertile branch; o. outer sepal (left), inner sepal (right). p-r. Ipomoea marcellia (R. Pereira 2725) - p. calyx e bracteoles, lateral view; q. outer sepals; r. inner sepals. 
ca. $7 \mathrm{~mm}$ compr., rotácea. Fruto ca. $5 \mathrm{~mm}$ compr., ovoide.

Material examinado: Trilha das Conchas, 12.III.2006, fl. e fr., M.T. Vital et al. 21 (UFP).

Endêmica do Brasil e da Caatinga, ocorrendo apenas na Bahia e em Pernambuco (Bianchini \& Ferreira, 2013), em áreas com solos arenosos. No PARNA Catimbau é encontrada em vegetação arbustiva perenifólia, e é considerada rara, podendo ser facilmente reconhecida por ser a única espécie do gênero com sépalas de ápice ciliado e obtuso.

2. Evolvulus elegans Moric., P1. Nouv. Am.: 53. 1838 .

Fig. 1c

Ervas ou subarbustos eretos. Ramos glabrescentes a seríceos. Folhas 5-7 × 0,5-1 $\mathrm{mm}$, cartáceas, densamente seríceas em ambas as faces, lineares a lanceoladas, ápice agudo, base cuneada, discolores; pecíolo até $1 \mathrm{~mm}$ compr.. Flores solitárias ou em monocásios com 2-3 flores, axilares; pedúnculo 0,5-2 cm compr., seríceo; bractéolas 0,5-1 mm compr., lineares; pedicelo ca. $2 \mathrm{~mm}$ compr.; sépalas iguais entre si, ca. 1,5 × 2 $\mathrm{mm}$, seríceas, ovais a elípticas, ápice acuminado, base atenuada; corola 5-7 mm compr., rotácea. Fruto ca. $2 \mathrm{~mm}$ compr., ovoide.

Material selecionado: Serra de Jerusalém, 12.IX.2012, fl., G.C. Delgado-Junior \& S.O. Santos 662 (UFP). Sítio Cigano, 8.V.2013, fl., G.C. Delgado-Junior et al. 643 (UFP). Vale do Catimbau, 20.II.2002, fl. e fr., I.C. Machado et al. s.n. (UFP 31787).

Ocorre na Bolívia, Paraguai, Venezuela e Brasil (Junqueira \& Bianchini 2006), onde é encontrada nos estados do Ceará, Pernambuco, Bahia, São Paulo, Minas Gerais, Goiás e Mato Grosso do Sul (Bianchini \& Ferreira 2013). É abundante nas distintas fitofisonomias do PARNA Catimbau e é diferenciada das demais pelas folhas discolores e densamente seríceas.

3. Evolvulus frankenioides Moric., $\mathrm{Pl}$. Nouv. Am.: 49. 1838 .

Fig. 1d-g

Ervas prostradas. Ramos densamente vilosos. Folhas $1-1,5 \times 0,6-0,9 \mathrm{~cm}$ cartáceas, vilosaseríceas em ambas as faces, oblíquas a ovais, ápice agudo, base arredondada, às vezes cuneada, não discolores; pecíolo até $1 \mathrm{~mm}$ compr.. Flores solitárias ou em monocásios com até 2 flores, axilares; pedúnculo ca. $3 \mathrm{~mm}$ compr., lanuginoso; bractéolas 1,5-2 mm compr., lanceolares a lineares; pedicelo ca. $2 \mathrm{~mm}$ compr.; sépalas subiguais entre si, 4-5 × $1 \mathrm{~mm}$, viloso-tomentosas, lanceoladas, ápice agudo, base cuneada; corola ca. $6 \mathrm{~mm}$ compr., infundibuliforme. Fruto ca. 3 mm compr., globoide.

Material selecionado: Fazenda Brejo de São José, 16.I.2013, fl. e fr., G.C. Delgado-Junior et al. 594 (UFP). Trilha Caiana, 6.VIII.2006, bt. e fl., M.T.Vital 35 (UFP) Vale do Catimbau, 11.III.2006, fl., M.T. Vital et al. 19 (UFP).

Distribui-se na Venezuela, Bolívia e no Brasil (Ooststroom 1934), onde é encontrada principalmente na Caatinga e Cerrado, mas também ocorre na Mata Atlântica (Bianchini \& Ferreira 2013). No PARNA Catimbau, é abundante, ocorrendo principalmente em áreas degradadas e caatinga arbustiva. É facilmente reconhecida pelo hábito prostrado, com folhas oblíquas e ramos vilosos.

4. Evolvulus glomeratus Nees \& Mart., Nova Acta Phys.-Med. Acad. Caes. Leop.-Carol. Nat. Cur. 11(1): 81. 1823.

Fig. 1h-j

Subarbustos eretos. Ramos vilosos. Folhas 1,5-2 × 2-3 cm, cartáceas, vilosas em ambas as faces, lanceoladas, oblongas, elípticas, ápice agudo ou obtuso, mucronado, base cuneada ou atenuada, não discolores; pecíolo até $1 \mathrm{~mm}$ compr.. Flores em glomérulos congestos ou alongados, axilares ou terminais; pedúnculo ausente; bractéolas ca. 7 mm compr., estreito-elíptica a lanceolado; pedicelo ausente; sépalas iguais entre si, 7-8 × $1 \mathrm{~mm}$, vilosas, lanceoladas, ápice agudo, base cuneada; corola ca. $1 \mathrm{~cm}$ compr., infundibuliforme. Fruto ca. $3 \mathrm{~mm}$ compr., ovoide.

Material selecionado: Serra de Jerusalém, 12.IX.2012, fl., G.C. Delgado-Junior \& S.O. Santos 663 (UFP). Trilha Caiana, 6.VII.2006, fl. e fr., M.T. Buril et al. 36 (UFP).

Amplamente distribuída na América do Sul. No Brasil, ocorre em quase todos os domínios fitogeográficos, exceto no Pantanal (Bianchini \& Ferreira 2013. No PARNA Catimbau é abundante, ocorrendo em caatinga arbustiva de solos arenosos e pedregosos. Apresenta grande plasticidade morfológica, tanto foliar quanto no indumento e na inflorescência. Na área de estudo, encontram-se indivíduos com diferentes formas e tamanhos de folhas, ramos com indumento dourado, ferrugíneo a esbranquiçado quando herborizadas, e com inflorescências axilares ou terminais, congestas ou alongadas, demonstrando ampla variabilidade desta espécie. Distribui-se pela vegetação arbustiva perenifólia, caatinga arbustiva e afloramentos rochosos. É reconhecida na área por ser a única espécie do gênero com inflorescência glomerular terminal ou axilar. 
Ipomoea L., Sp. pl. 1: 159. 1753.

Trepadeiras lenhosas ou herbáceas, subarbustos prostrados ou arbustos; látex presente ou ausente; tricomas simples. Folhas simples ou compostas, inteiras ou lobadas, margem inteira ou denteada, pecioladas, nectários por vezes presentes. Inflorescência axilar; bractéolas presentes ou ausentes. Sépalas iguais, subiguais ou desiguais; corola inteira a levemente lobada, plicada, roxa, rósea, vermelha, branca ou amarela, glabra ou indumentada; estames 5, inclusos ou raramente exsertos, anteras oblongas; ovário globoso, bilocular, 1-2 óvulos por lóculos, glabro; estilete 1, estigmas 2, globosos. Fruto cápsula, deiscente; sementes 4 .

5. Ipomoea asarifolia Roem. \& Schult., Syst. Veg., ed. 15, 4: 251. 1819.

Subarbustos prostrados; látex branco. Ramos glabros. Folhas inteiras, 3-6 × 2,5-6,5 cm, cartáceas, margem inteira, glabras em ambas as faces, reniformes a deltoides, ápice arredondado a emarginado, mucronado, base truncada a levemente cordada; pecíolo 3-8 cm compr., glabro. Dicásios, 4 flores; pedúnculo 3-8 cm compr., glabrescente; bractéolas ca. $2 \mathrm{~mm}$ compr., deltoide; pedicelo 0,5-2 cm compr.; sépalas desiguais entre si, externas $0,5-0,6 \times 0,4-0,5 \mathrm{~cm}$, glabras, rotundas, ápice arredondado a emarginado, mucronado, base arredondada, internas $1,3-1,5 \times 1-1,3 \mathrm{~cm}$, glabras, obovais a orbiculares, ápice obtuso, mucronado, base truncada; corola ca. $8 \mathrm{~cm}$ compr., infundibuliforme, glabra, roxa. Estames inclusos. Fruto ca. $1 \mathrm{~cm}$ compr., ovoide.

Material selecionado: Alcobaça, 9.V.2013, fl., G.C. Delgado-Junior et al. 657 (UFP). Trilha para Vila do Catimbau, 7.V.2013, fl., G.C. Delgado-Junior et al. 624 (UFP).

Material adicional: BRASIL. PERNAMBUCO: Triunfo, 3.XII.2000, fl. e fr., C. Schlindwein 31 (UFP).

Ocorre em todas as Américas, e no Brasil está presente na Amazônia, Caatinga e Mata Atlântica (Bianchini \& Ferreira 2013). No PARNA Catimbau, é ocasional e ocorre em beira de estrada. É facilmente identificada pelas folhas reniformes a deltoides e pelo hábito prostrado.

6. Ipomoea bahiensis Willd. ex Roem. \& Schult., Syst. Veg., ed. 15, 4: 789. 1819.

Trepadeiras herbáceas; látex branco. Ramos glabros a glabrescentes. Folhas inteiras, 2,5-6 $\times 0,5-3 \mathrm{~cm}$, membranáceas a cartáceas, margem inteira, glabras a pubescentes em ambas as faces, sagitadas a cordadas, ápice agudo, mucronado, base cordada; pecíolo 2,5-6,5 cm compr., glabro a glabrescente. Dicásios, 6 flores; pedúnculo 3-15 cm compr., pubescente; bractéolas ca. $2 \mathrm{~mm}$ compr., lineares; pedicelo ca. $2 \mathrm{~mm}$ compr.; sépalas desiguais entre si, externas $0,6-0,7 \times 0,3-0,4 \mathrm{~cm}$, glabras, rugosas, ovais, ápice apiculado e com rostro subapical $\leq 1 \mathrm{~mm}$ compr., base truncada, internas ca. $0,7 \times 0,5 \mathrm{~cm}$, glabras, rugosas, margem escariosa; rotundas, ápice arredondado, base truncada, corola ca. $4 \mathrm{~cm}$ compr., infundibuliforme, glabra, rosa; estames inclusos. Fruto ca. $9 \mathrm{~mm}$ compr., ovoide.

Material selecionado: Trilha para Vila do Catimbau, 7.V.2013, fl., G.C. Delgado-Junior et al 623 (UFP). Vale do Catimbau, 29.IX.2004, fl. e fr., R.A. Pick 56 (UFP).

Endêmica do Brasil, ocorrendo na Amazônia, Caatinga, Cerrado e Mata Atlântica, nos estados do Norte ao Sudeste (Bianchini \& Ferreira 2013). No PARNA Catimbau é ocasional, ocorrendo em beira de estrada e em áreas degradadas, raramente em solos arenosos. É reconhecida pelas sépalas com rostro subapical e folhas sagitadas a cordadas. Pode ser confundida com $I$. af. vestalli devido à presença de folhas sagitadas, contudo esta não possui sépalas com rostro subapical.

7. Ipomoea brasiliana (Choisy) Meisn. in Mart., Fl. bras. 7: 261. 1869.

Fig. 1k-m

Trepadeiras lenhosas; látex branco. Ramos vilosos. Folhas inteiras, $3-3,5 \times 2,5-3,5 \mathrm{~cm}$, cartáceas, margem inteira, vilosas em ambas as faces, cordadas, ápice agudo, base cordada; pecíolo 1,5-2 cm compr., viloso. Flores solitárias ou em dicásios, 3 flores; pedúnculo $3-4$ cm compr., viloso; bractéolas ausentes; pedicelo ca. $2 \mathrm{~mm}$ compr.; sépalas desiguais entre si, externas ca. $0,8 \times 0,7$ $\mathrm{cm}$, glabras a glabrescentes, margem escariosa, orbiculares a rotundas, ápice arredondado, base arredondada, internas ca. $0,7 \times 0,5 \mathrm{~cm}$, glabras, margem escariosa, obovais a rotundas, ápice arredondado, base truncada; corola ca. $5 \mathrm{~cm}$ compr., infundibuliforme, glabra, rosa; estames inclusos. Fruto ca. 1,5-2 cm compr., globoide.

Material selecionado: Chapada São José, 5.V.95, fl., M.J.N Rodal \& A.P.S. Gomes 533 (PEUFR). Fazenda Laranjeira, 09.VII.1995, fr., L. S. Figueiredo et al. 109 (PEUFR). Serra de Jerusalém, 12.IX.2012, fl., G.C. Delgado-Junior \& S.O. Santos 453 (UFP). Trilha para o Sítio Juá, 8.V.2013, fl., G.C. Delgado-Junior et al. 642 (UFP).

Ocorre apenas no Brasil, especificamente, em todo o Nordeste, Distrito Federal e Minas Gerais 
(Bianchini \& Ferreira 2013), sendo endêmica da Caatinga e do Cerrado. No PARNA Catimbau, é abundante, ocorrendo em afloramentos rochosos e caatingas arbustivas com solos arenosos e pedregosos. É reconhecida pelas sépalas glabras a glabrescentes, ramos e folhas vilosos. $\mathrm{Na}$ área de estudo, é facilmente confundida com Ipomoea subincana, a qual pode ser distinguida por apresentar sépalas vilosas e sépalas externas pubescentes e um pouco menores que as internas. Pode ainda ser confundida com a Turbina cordata a qual pode ser diferenciada por apresentar corola com vilosidade na nervura mesopétala e a face adaxial da folha glabrescente com tricomas restritos as nervuras, além dos frutos indeiscentes.

8. Ipomoea carnea subsp. fistulosa (Mart. ex Choisy) D.F.Austin, Taxon 26: 237. 1977.

Arbustos eretos; látex branco. Ramos puberulentos a glabrescentes. Folhas inteiras, 10-16 x 3-4,5 cm, cartáceas, margem inteira, puberulentas a glabrescentes em ambas as faces, lanceoladas, ápice acuminado, base cordada a truncada; pecíolo 4-6 cm compr., pubescente. Dicásios, 6 flores; pedúnculo 3-9 cm compr., pubescente; bractéolas ausentes; pedicelo $0,5-1,7 \mathrm{~cm}$ compr., nectários presentes; sépalas desiguais entre si, externas 6-7 × $6 \mathrm{~mm}$, glabrescentes, ovais a subrotundas, ápice arredondado, base arredondada, internas 6-8 x $9 \mathrm{~mm}$, pubescentes, deltoides a ovais, ápice arredondado a agudo, base arredondada; corola ca. $5 \mathrm{~cm}$ compr., infundibuliforme, pubescente, rosa; estames inclusos. Fruto ca. 1,3 cm compr., ovoide. Material examinado: Paraíso Selvagem, 11.I.1996, fl., E. Freire et al 26 (PEUFR).

Material adicional: PERNAMBUCO: Barra da Jangada, 19.X.2002, fr., J.L.H. Alves et al. (UFP 33776).

Distribuída nas Américas (Austin \& Huáman 1996), Ásia e Oceania (Rhui-cheng \& Staples 1995; Fosberg \& Sachet 1977). No Brasil, é amplamente cultivada como ornamental. (Bianchini \& Ferreira 2013, Bianchini 1998). É rara e encontrada no PARNA Catimbau em áreas antropizadas e em cultivo, sendo a única espécie do gênero com hábito arbustivo ereto.

9. Ipomoea hederifolia L., Syst. Nat., ed. 10, 2: 925. 1759.

Trepadeiras lenhosas; látex ausente. Ramos glabros a glabrescentes. Folhas discretamente lobadas, 8-18 × 5-14,5 cm, cartáceas, margem inteira ou com 1 a 2 dentes em cada lado, glabras em ambas as faces, ápice agudo, base profundamente cordada; pecíolo 3-13 cm compr., glabro. Dicásios, 8 flores; pedúnculo 9-25 cm compr., glabro; bractéolas ausentes; pedicelo 2-7 $\mathrm{mm}$ compr; sépalas desiguais entre si, externas $2-3 \times 2 \mathrm{~mm}$, glabras, rotundas, ápice arredondado e com rosto subapical ca. 3,5 mm compr., base arredondada, internas 2,5-3 $\times 3 \mathrm{~mm}$, glabras, rotundas, ápice arredondado, base arredondada; corola ca. $5 \mathrm{~cm}$ compr., hipocrateriforme, glabra, vermelha; estames exsertos. Fruto ca. $5 \mathrm{~mm}$ compr., globoide.

Material examinado: Vale do Catimbau, 17.VI.2008, fl., R. Pereira 2833 (IPA).

Material adicional: BRASIL. PERNAMBUCO: Recife, Campus UFPE, 14.VI.1994, fl. e fr., T. Praciano (PEUFR 17921).

Amplamente distribuída nas Américas (Austin \& Huáman 1996), ocorrendo desde os Estados Unidos a Argentina, no Brasil encontra-se em quase todo território (Bianchini \& Ferreira 2013). No PARNA Catimbau, ocorre em áreas antropizadas, porém é rara. Diferencia-se das outras espécies do gênero pela corola hipocrateriforme e vermelha.

10. Ipomoea longeramosa Choisy. in A. P. de Candolle, Prodr. 9: 384. $1845 . \quad$ Fig. 1n-o

Trepadeiras herbáceas; látex ausente. Ramos hirsutos. Folhas 5-lobadas, ca. $4 \times 6$ $\mathrm{cm}$, membranáceas, margem inteira e ciliada, glabrescentes em ambas as faces, com tricomas restritos as nervuras, lobos ovais ou elípticos, ápice agudo a arredondado e mucronado, base assimétrica; pecíolo 2,5-3 cm compr., esparsamente piloso. Monocásio, 2 flores; pedúnculo ca. $3 \mathrm{~cm}$ compr., hirsuto apenas na região terminal; bractéolas ca. $3 \mathrm{~mm}$, compr., lineares; pedicelo 1-2 cm compr.; sépalas desiguais entre si, externas 9-11 × 3-4 $\mathrm{mm}$, glabrescentes, lanceoladas a oblongas, ápice apiculado, base truncada, internas 7-10 × 3-4 mm, glabras, lanceoladas, ápice apiculado, base truncada; corola ca. 2-2,5 cm compr., infundibuliforme, glabra, amarela com fauce vinácea; estames inclusos. Fruto ca. $5 \mathrm{~mm}$ compr., globoide.

Material examinado: Estrada para o Alcobaça, 31.VIII. 2013, fl. e fr., G.C. Delgado-Junior et al. 695 (UFP). Vale do Catimbau, 19.VI.2008, bt. e fl., R. Pereira 2706 (IPA). Material adicional: BRASIL. PERNAMBUCO: Salgueiro, Povoado de Uri, 21.VII.2009, fl. e fr., M.Oliveira et al. 2202 (UFP).

Distribuída na Venezuela e Brasil, onde é encontrada na Caatinga e no Cerrado. No PARNA Catimbau é rara e pode ser encontrada em áreas de caatinga arbustiva. É a única espécie do gênero com corola amarela com fauce vinácea e folhas 5-lobadas. 
11. Ipomoea marcellia Meisn. in Mart., Fl. bras. 7: 257.1869.

Fig. 1p-r

Trepadeiras lenhosas; látex ausente. Ramos vilosos. Folhas inteiras, $4-8 \times 3,5-7,5 \mathrm{~cm}$, cartáceas, margem inteira, vilosas em ambas as faces, cordadas a ovais, ápice agudo, base cordada; pecíolo 2-3,5 cm compr., viloso. Dicásios, até 20 flores; pedúnculo $20-35 \mathrm{~cm}$ compr., viloso; bractéolas ca. 1,5 cm compr., elípticas; pedicelo ca. $5 \mathrm{~mm}$ compr.; sépalas desiguais entre si, externas 1,2-1,5 ×0,5-0,7 cm, vilosas, ovais, ápice obtuso a agudo, base cuneada, internas $0,9-1,1 \times$ $0,6-0,7 \mathrm{~cm}$, vilosas, ovais, ápice arredondado, base truncada; corola 3-5 cm compr., infundibuliforme, vilosa, branco-amarelada; estames exsertos. Fruto ca. $1 \mathrm{~cm}$ compr., ovoide.

Material selecionado: Igrejinha, 2.IV.2012, fl., G.C. Delgado-Junior et al. 297 (UFP). Vale do Catimbau, 19.VI.2008, fl., R. Pereira 2725 (IPA). Vale do Catimbau, VII.2007, fl. e fr., O. Cano et al. 795 (IPA).

É endêmica da Caatinga (Bianchini \& Ferreira 2013) e associada a ambientes não perturbados (Vital 2009). No PARNA Catimbau é ocasional, encontrada principalmente em caatinga arbustiva de solos pedregosos, podendo também ocorrer em áreas com solo arenoso. É reconhecida pela corola branco-amarelada, vilosa e face abaxial das folhas densamente vilosas e com nervuras proeminentes.

12. Ipomoea nil (L.) Roth., Catal. Bot. 1: 36. 1797.

Trepadeiras lenhosas; látex ausente. Ramos hirsutos. Folhas trilobadas, 5-8,5 × 4-6,5 cm, membranáceas, margem inteira ou com dentes em cada lado, esparsamente hirsutas em ambas as faces, ovais, ápice agudo a acuminado, base cordada; pecíolo 1,5-5 $\mathrm{cm}$ compr., hirsuto. Dicásios, 3 flores; pedúnculo $3-8 \mathrm{~cm}$ compr., hirsuto; bractéolas 5-9 $\mathrm{mm}$ compr., lineares; pedicelo $0,9-1,5 \mathrm{~cm}$ compr.; sépalas iguais entre si, $1,5-3 \times 0,2-0,5 \mathrm{~cm}$, ovais ou lanceoladas, ápice caudado, base arredondada densamente hirsuta; corola 3-5 cm compr., infundibuliforme, glabra, rosa, lilás ou azul com fauce branca; estames inclusos. Fruto ca. 1,5-2 cm compr., globoide.

Material selecionado: Estrada para o Alcobaça, 31.VIII.2012, fl., G.C. Delgado-Junior et al. 690 (UFP). Caiana, 6.VII.2006, fl. e fr., M.T. Buril et al. 41 (UFP).

Possui distribuição pantropical (Bianchini 1998) e, no Brasil, ocorre em todo território (Bianchini \& Ferreira 2013). No PARNA Catimbau é ocasional e ocorre principalmente em áreas degradadas e cultivadas, bem como em áreas de caatinga arbustiva em solo arenoso. É reconhecida pelas sépalas iguais entre si com ápice caudado e densamente hirsutas na base.

13. Ipomoea pintoi O'Donell., Lilloa 26: 380. 1953.

Fig. 2a-d

Trepadeiras lenhosas; látex ausente. Ramos glabros. Folhas inteiras, 3-7 × 1-3 cm, cartáceas, margem inteira, glabras em ambas as faces, elípticas a oblanceoladas, ápice acuminado, base cuneada; pecíolo $0,5-0,8 \mathrm{~cm}$ compr., glabro, nectários presentes. Dicásios, 4 flores; pedúnculo 1,5-2 cm compr., glabro; pedicelo 0,5-1 cm compr., nectários presentes; sépalas iguais a subiguais entre si, 5-6 × 3-0,5 mm, glabras, obovais, côncavas, ápice arredondado, base atenuada; corola ca. $4 \mathrm{~cm}$ compr., infundibuliforme; glabra, rosa; estames inclusos. Fruto ca. $5 \mathrm{~mm}$ compr., globoide.

Material selecionado: Igrejinha, 8.VIII. 2012, fr., G.C. Delgado-Junior \& S.O. Santos 404 (UFP). Serra Branca, 8.VII.2012, fl., G.C. Delgado-Junior \& S.O. Santos 391 (UFP). Serra de Jerusalém, 7.VII.2012, fl.e fr., G.C. Delgado-Junior 347 (UFP).

Endêmica da Caatinga, ocorrendo em Pernambuco, Sergipe e Bahia. É abundante nas diversas fitofisionomias do PARNA Catimbau e reconhecida por ser glabra e apresentar folhas elípticas a oblanceoladas e nectários no pecíolo e pedicelo.

14. Ipomoea piurensis O'Donell, Lilloa 26: 381 1953.

Fig. 2e-g

Trepadeiras lenhosas; látex ausente. Ramos glabros. Folhas inteiras, 3,5-10 × 3-9,0 cm, cartáceas, margem inteira ou com 1 a 3 dentes em cada lado, glabras na face adaxial e com tricomas nas nervuras da face abaxial, cordada, ápice agudo, mucronado, base cordada; pecíolo 2,5-6,5 cm compr., glabro. Dicásios, 4 flores; pedúnculo 1,5-4 cm compr., glabrescente; bractéolas ca. $3 \mathrm{~mm}$ compr., deltoide; pedicelo 3-6 mm compr.; sépalas desiguais entre si, externas $0,7-0,9 \times 0,4-0,6 \mathrm{~cm}$, glabras, rugosas, margem escariosa, ovais, ápice acuminado, mucronado, base arredondada, internas $0,6-0,9 \times 0,4-0,7 \mathrm{~cm}$, glabras, lisas a levemente rugosa, ovais, ápice acuminado, mucronado, base arredondada; corola ca. 2,5 cm compr., infundibuliforme, glabra, rosa claro; estames inclusos. Fruto não observado

Material examinado: Estrada para o Alcobaça, 31.VIII. 2013, fl., G.C. Delgado-Junior et al. 691 (UFP).

Ocorre nas Américas Central e do Sul. É encontrada no Norte e Nordeste do Brasil. No 

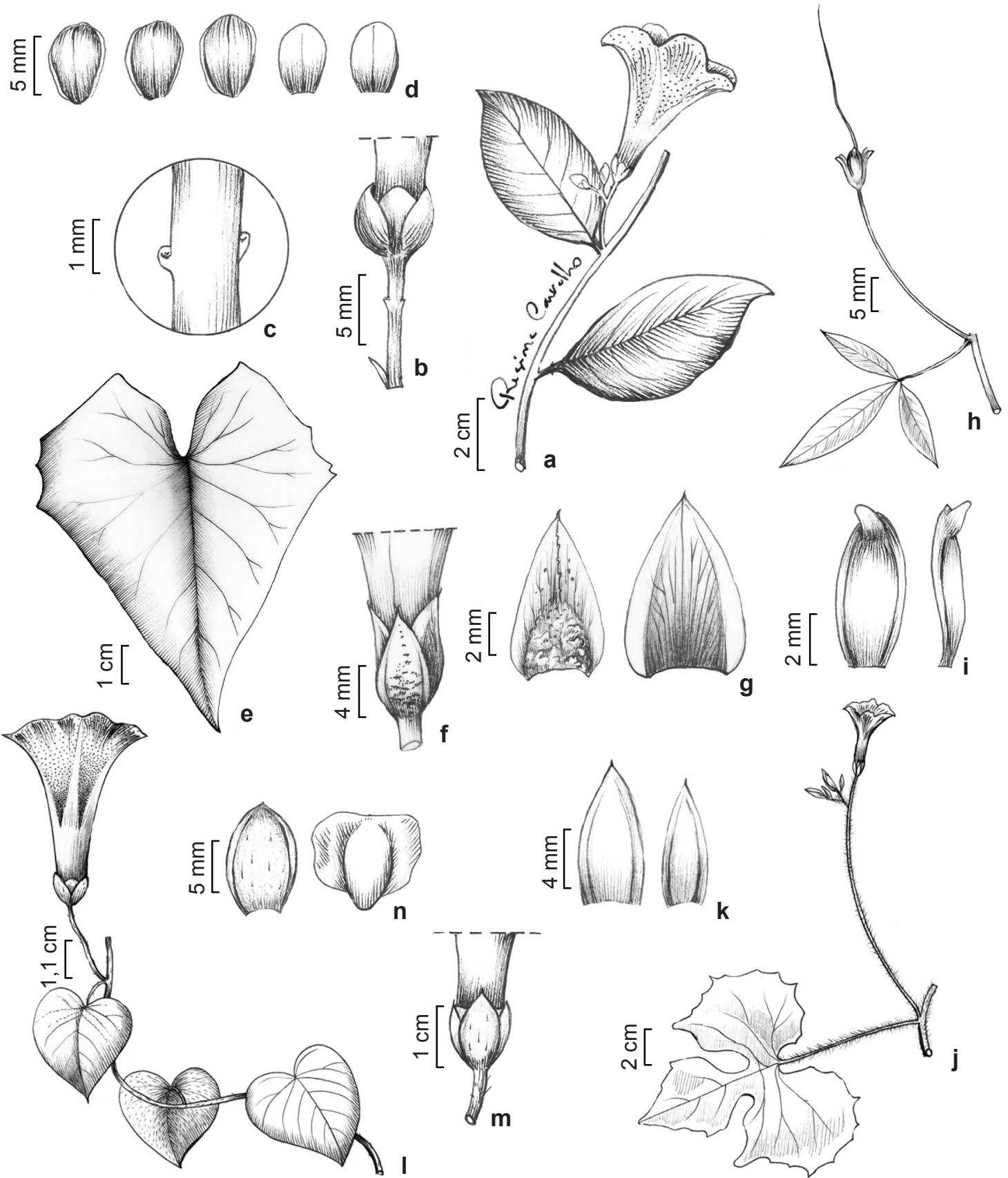

Figura 2 - a-d. Ipomoea pintoi (G.C. Delgado Junior 368) - a. ramo florífero; b. cálice, vista lateral; c. nectários do peciolo; d. sépalas, externas a internas (da esquerda para direita). e-g Ipomoea piurensis (G.C.Delgado-Junior 691 ) - e. folha; f. cálice, vista lateral; g. sépala externa (esquerda), sépala interna (direita). h-i. Ipomoea rosea (G.C. Delgado-Junior 619) - h. ramo fértil; 1. sépalas externas, vista frontal e lateral. j-k Ipomoea setosa (R. Pereira 2702) - j. ramo florífero; k. sépala externa (esquerda), sépala interna (direita). 1-n Ipomoea subalata (G.C. Delgado-Junior $364)$ - 1. ramo florífero; $n$. sépala externa (esquerda), sépala interna (direita); $m$. cálice, vista lateral.

Figure 2 - a-d. Ipomoea pintoi (G.C. Delgado Junior 368) - a. fertile branch; b calyx; c. nectaries of petiole. d. sepals, outer to inners (from left to right). e-g Ipomoea piurensis (G.C. Delgado-junior 691) - e. left; f. calyx, lateral view; g. outer sepal (left), inner sepal (direita). h-i. Ipomoea rosea (G.C. Delgado-Junior 619) - h. fertile breach; i. outer sepal, frontal and lateral view. ). j-k. Ipomoea setosa (R. Pereira 2702) - j. fertile branch; k. outer sepal (left), inner sepal (right). 1-n. Ipomoea subalata (G.C. Delgado-Junior 364) - 1. fertile breach; n. outer sepal (left), inner sepal (right), lateral view. 
PARNA Catimbau é rara, ocorrendo principalmente em solos arenosos. Diferencia-se das demais por apresentar sépalas externas rugosas e glabras e corola com até $2,5 \mathrm{~cm}$ de compr.

15. Ipomoea rosea Choisy. in A.P. de Candolle, Prodr. 9: 384. 1845.

Fig. 2h-i

Trepadeiras herbáceas; látex branco. Ramos glabros a glabrescentes. Folhas 3-folioladas 1,5-3 $\times 0,4-0,7 \mathrm{~cm}$, membranáceos, margem inteira, glabras em ambas as faces, folíolos elípticos, ápice agudo, mucronado, base cuneada; pecíolo 1,3-1,5 cm compr., glabro. Dicásios, até 8 flores; pedúnculo 1-2,5 cm compr., glabro; bractéolas ca. $1 \mathrm{~mm}$ compr., lineares; pedicelo ca. $5 \mathrm{~mm}$ compr.; sépalas iguais entre si, ca. $6 \times 3 \mathrm{~mm}$, glabras, estreito elípticas a obovais, ápice arredondado e com rostro subapical, <2 mm compr., base truncada, carnosas; corola ca. $7 \mathrm{~cm}$ compr., infundibuliforme, glabra, rosa; estames inclusos. Fruto ca. $8 \mathrm{~mm}$ compr., globoide.

Material selecionado: Igrejinha, 6.V.2013, fl., G.C. Delgado-Junior et al. 619 (UFP). Serra de Jerusalém, 30.V.2012, bt., G.C. Delgado-Junior \& S.O. Santos 318 (UFP). Serra Branca, 8.VII.2012, fr., G.C. DelgadoJunior \& S.O. Santos 338 (UFP).

Endêmica da Caatinga, ocorrendo do Ceará à Bahia. No PARNA Catimbau é abundante, ocorrendo principalmente em caatinga arbustivas de solos arenosos e pedregosos. Diferencia-se das demais por ser a única espécie de Ipomoea com folhas trifolioladas e sépalas carnosas com rostro subapical.

16. Ipomoea setosa Ker Gawl., Bot. Reg. 4: 335. 1818.

Fig. $2 \mathrm{j}-\mathrm{k}$

Trepadeiras lenhosas; látex não observado. Ramos hirsutos. Folhas 3-5 lobadas, 7-15 × 10-13 $\mathrm{cm}$, membranáceas, margem denteada, glabras em ambas as faces, ovais, ápice acuminado, base profundamente cordada; pecíolo 5-10 cm compr., hirsuto. Dicásios, ca. 12 flores; pedúnculo 10-12 cm compr., hirsuto; bractéolas 3-6 mm compr., lanceoladas; pedicelo 0,8-2 cm compr.; sépalas subiguais entre si, $1-1,2 \times 0,4-0,5 \mathrm{~cm}$, glabras, ovais, ápice agudo e mucronado, base truncada; corola ca. $4 \mathrm{~cm}$ compr., infundibuliforme, glabra, rosa; estames inclusos. Fruto ca. 1,5 cm compr., globoide.

Material examinado: Sítio Serrote Preto, 19.VI.2008, fl., R. Pereira 2702 (IPA).

Material adicional: BRASIL. CEARÁ: Maracanaú, Pau Serrado, VI.1956, fl. e fr., A. Ducke et al. 2544 (IPA).
Ocorre nas Américas e na China (Austin \& Huáman 1996; Rhui-cheng \& Staples 1995), no Brasil está distribuída do Nordeste ao Sudeste, na Caatinga, Cerrado e Mata Atlântica (Bianchini \& Ferreira 2013). No PARNA Catimbau é rara e encontrada em solos arenosos. Distingue-se das demais por apresentar ramos com tricomas longos, folhas lobadas de margem denteadas e sépalas glabras e mucronadas.

17. Ipomoea subalata Hassl., Repert. Spec. Nov. Regni Veg. 9: 157. 1911.

Fig. 21-n

Trepadeiras herbáceas; látex branco. Ramos glabrescentes. Folhas inteiras, 3-5 × 2,5-3,5 cm, membranáceas, margem inteira, face adaxial glabra, face abaxial pubescente, cordadas, ápice acuminado, base cordada; pecíolo 2-3 cm compr., esparsamente pubescente. Dicásios, 3 a 9-flores; pedúnculo 2-4 cm compr., esparsamente pubescente; pedicelo 1-1,2 cm compr.; sépalas desiguais entre si, externas $0,8-1 \times 0,6-0,7 \mathrm{~cm}$, coriáceas, glabrescentes, margem ciliada, ovais, ápice agudo, base cuneada, internas ca. 0,7-1,1 $\times$ $0,9 \mathrm{~cm}$, membranáceas, glabras, margem escariosa, orbiculares ou assimétricas, ápice retuso, base truncada; corola 5-6 cm compr., infundibuliforme, glabra, rosa; estames inclusos. Fruto ca. $5 \mathrm{~mm}$ compr., globoide.

Material selecionado: Sítio Breu, 01.VI.2012, fl., G.C. Delgado Junior 364 (UFP). Casa de farinha, 31.V.2012, fl. e fr., G.C. Delgado-Junior 346 (UFP),

Ocorre no Paraguai e Brasil, onde é referenciada no Maranhão, Pernambuco e Bahia (Austin \& Huáman 1996; Bianchini \& Ferreira 2013). No PARNA, é ocasional e reconhecida pelas sépalas externas coriáceas com tricomas esparsos e as internas com margem escariosa. É encontrada em caatinga arbustiva de solo arenoso.

18. Ipomoea subincana (Choisy) Meisn. in Mart., F1. bras. 7: 259 .

Fig. 3a-b

Trepadeiras lenhosas; látex branco. Ramos vilosos. Folhas inteiras, 4,5-6,5 × 2,5-4,5 cm, cartáceas, margem inteira, vilosas em ambas as faces, cordadas, ápice agudo, mucronado, base cordada; pecíolo 2-3,5 cm compr., viloso. Dicásios, 3 flores; pedúnculo 1-1,5 cm compr., densamente viloso; bractéolas ausentes, pedicelo ca. 0,5 cm compr.; sépalas desiguais entre si, externas ca. $0,7 \times 0,8 \mathrm{~cm}$, vilosas, ovais a rotundas, ápice arredondado, base cuneada, internas ca. $0,8 \times 0,8 \mathrm{~cm}$, glabras a glabrescentes, margem 

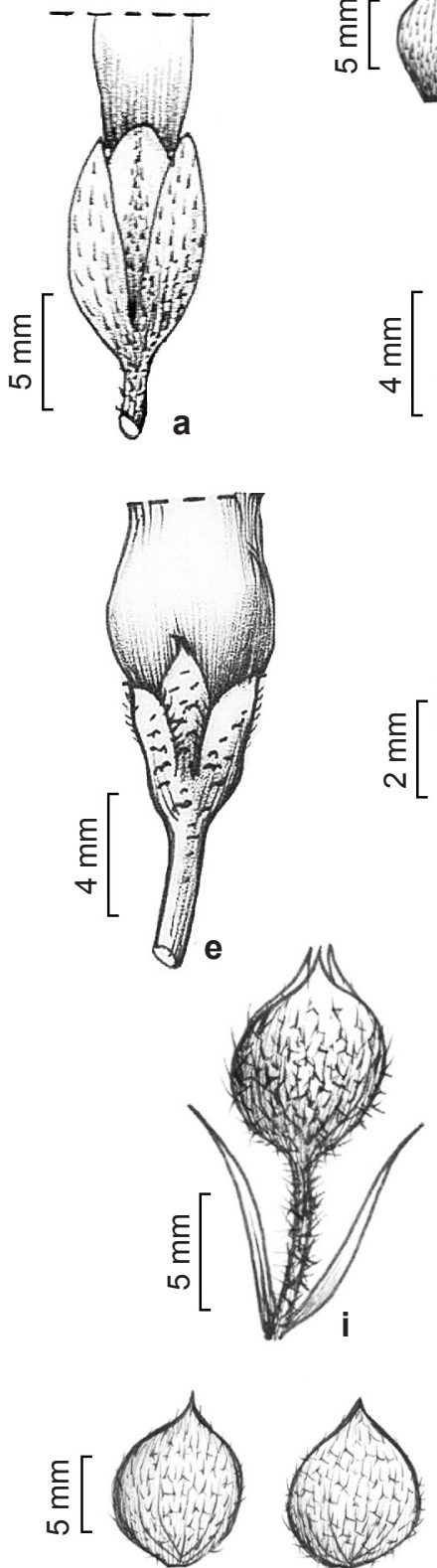
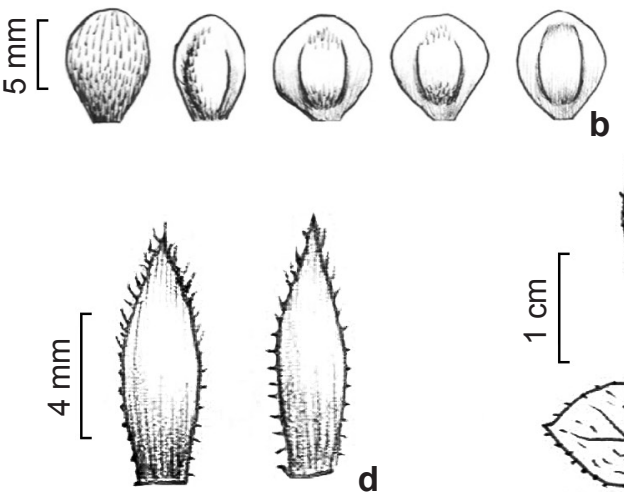
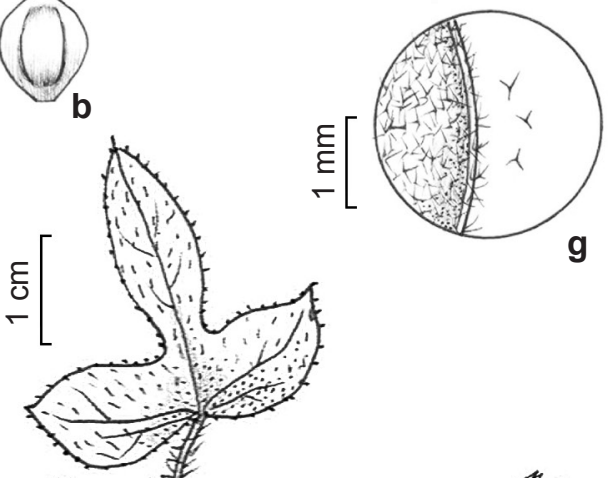

g
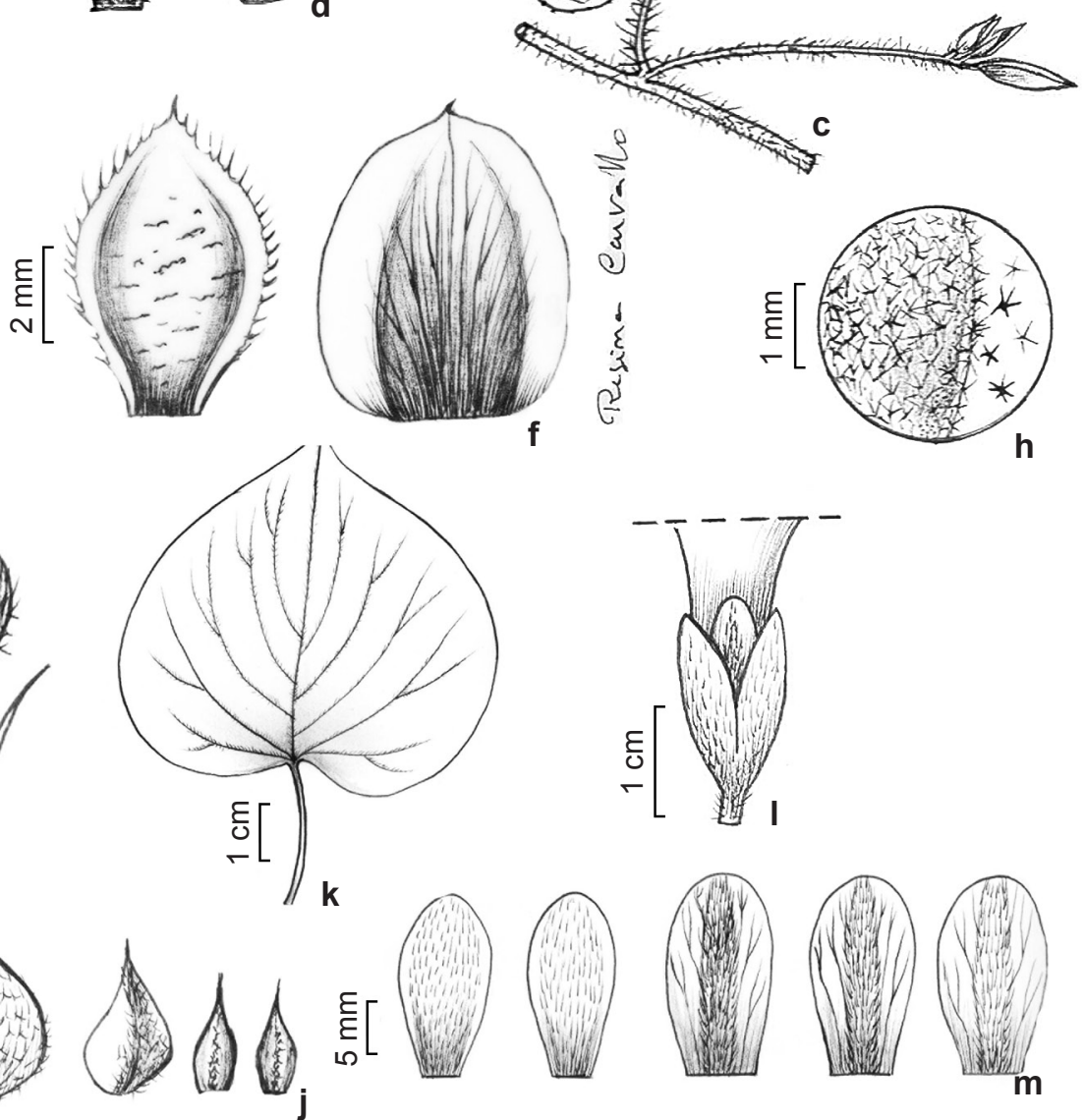

Figura 3 - a-b. Ipomoea subincana (G.C. Delgado Junior 308) - a. cálice, vista lateral; b. sépalas, externas a internas (da esquerda para direita). c-d Ipomoea triloba (O. Cano 835) - c. ramo florífero. d. sépala externa (esquerda), sépala interna (direita); e-f. Ipomoea aff. vestalli.(G.C. Delgado 721) - e. cálice, vista lateral; f. sépala externa (esquerda), sépala interna (direita). g. Jacquemontia agrestis (G.C.Delgado Junior 468 ) -tricomas 3-armados. h. Jacquemontia chrysanthera ( G.C. Delgado Junior 439) - tricomas 5(7)-armados. i-j. Jacquemontia ferruginea var. ambigua (G.C. Delgado Junior 440) - i. cálice e bractéolas; j. sépalas, externas a internas (da esquerda para direita). k-m. Turbina cordata (R Pereira 2844) - $\mathrm{k}$. folha; 1 . cálice, vista lateral; $\mathrm{m}$. sépalas externas às internas (da esquerda para a direita). Figure 3 - a-b. Ipomoea subincana (G.C. Delgado Junior 308) - a. calyx, lateral view; b. sepals, outer to inners (from left to right). c-d Ipomoea triloba (O. Cano 835) - c. fertile breach; d. outer sepal (left), inner sepal (right). e-f. Ipomoea aff. vestalli.(G.C. Delgado 721 ) - e. calyx, lateral view; f. outer sepal (left), inner sepal (right). g. Jacquemontia agrestis (G.C.Delgado Junior 468) - trichomes 3-armed. h. Jacquemontia chrysanthera ( G.C. Delgado Junior 439) - trichomes 5(-7)-armed. i-j. Jacquemontia ferruginea var. ambigua (G.C. Delgado Junior 440) - i. calyx e bracteoles; j. sepals, outer to inners ( from left to right). k-m. Turbina cordata (R Pereira 2844 ) - k. leaf; 1. calyx, lateral view; m. sepals, outer to inners ( from left to right). 
escariosa, ovais, ápice arredondado, base truncada; corola ca. $5 \mathrm{~cm}$ compr., infundibuliforme, glabra, rosa; estames inclusos. Fruto ca. $5 \mathrm{~mm}$ compr., globoide.

Material selecionado: Chapadão, 2.IV.2012, fl., G.C. Delgado-Junior 296(UFP). Serra Branca, 31.V.2012. fl. e fr., G.C. Delgado Junior 329 (UFP). Serra Jerusalém 30.V.2012, fl., G.C. Delgado-Junior 308 (UFP).

É endêmica do Brasil, ocorrendo na Caatinga e no Cerrado. É abundante em todo PARNA Catimbau, principalmente em áreas arenosas, pedregosas e afloramentos rochosos, sendo reconhecida pelas sépalas externas ovais a rotundas, vilosas e as internas um pouco maiores que as externas e glabras. É confundida com Ipomoea brasiliana, mas esta possui sépalas externas glabras a glabrescentes e maiores que as internas, e com Turbina cordata que apresenta frutos indeiscentes e a face adaxial das folhas com tricomas ao longo das nervuras e a face abaxial densamente vilosa.

19. Ipomoea triloba L., Sp. pl. 1: 161. 1753. Fig. 3c-d

Trepadeiras herbáceas; látex branco. Ramos esparsamente pubescentes. Folhas inteiras ou trilobadas, 3,5-5 × 3-4,5 $\mathrm{cm}$, membranáceas, margem inteira e ciliada, glabras a esparsamente pubescentes em ambas as faces, ovais, ápice agudo a acuminado e mucronado, base cordada; pecíolo 1,5-2,5 cm compr., pubescente. Umbela, 4 flores; pedúnculo $2-3 \mathrm{~cm}$ compr., glabro; bractéolas ca. $5 \mathrm{~mm}$ compr., lineares; pedicelo $0,5-0,8 \mathrm{~cm}$ compr.; sépalas desiguais entre si, externas $0,8-0,9 \times 0,2-0,5 \mathrm{~cm}$, glabras, margem ciliada, elípticas a lanceoladas, ápice agudo, mucronado, base atenuada, internas $0,7-0,8 \times 0,4$ $0,5 \mathrm{~cm}$, glabras, margem esparsamente ciliada, ovais a elípticas, ápice agudo a acuminado, mucronado, base atenuada; corola ca. $2 \mathrm{~cm}$ compr., infundibuliforme, glabra, rosa; estames inclusos. Fruto ca. $5 \mathrm{~mm}$, subgloboide.

Material examinado: Alcobaça,VII.2007, bt. e f1., $O$. Cano et al. 835 (IPA).

Material Adicional: Pernambuco, Buíque, 01.IX.2013, fr., Delgado-Junior et al. 722 (UFP).

Ocorre nas Américas e na Ásia (Austin \& Huáman 1996, Rhui-cheng \& Staples 1995). No Brasil é amplamente distribuída principalmente na Caatinga, Cerrado e Mata Atlântica (Bianchini \& Ferreira 2013). É rara no PARNA Catimbau, ocorrendo em solos arenosos. Diferencia-se das demais espécies pelas folhas trilobadas ou inteiras e sépalas ciliadas.

20. Ipomoea aff. vestalii Standl., Contr. Arnold Arbor. 5: 130. 1933.

Fig. 3e-f

Trepadeiras herbáceas; látex não observado. Ramos glabros. Folhas inteiras, 3,0-7,0 × 2,5-4,5 $\mathrm{cm}$, cartáceas, margem inteira, pilosa, cordada a sagitada, ápice agudo, mucronado, base cordada; pecíolo 1,5-5 cm compr., pubescente. Dicásio, ca. 4 flores; pedúnculo 1,5-3 cm compr., pubescente; bractéolas ca. 2,5 mm compr., lanceoladas; pedicelo $0,5-1 \mathrm{~cm}$ compr.; sépalas desiguais entre si, externas, 4-6 × 0,3-0,4 cm, rugosas, glabras, margem ciliada e escariosa, ovais, ápice agudo, mucronado, base truncada, internas 5-7 $\times 5-6 \mathrm{~cm}$, lisas, glabras, margem escariosa, ovais a rotundas, ápice arredondado a subagudo, mucronado, base truncada; corola ca. $4 \mathrm{~cm}$ compr., infundibuliforme, glabra, rosa; estames inclusos. Fruto não observado.

Material selecionado: Estrada para trilha Caiana, 6.VII.2006, fl., M.T. Vital et al. 42 (UFP). Estrada para a Vila do Catimbau, 1.IX.2013, fl., G.C. Delgado-Junior et al. 721(UFP). Vale do Catimbau, 2.X.2004, fl., R.A. Pick 279 (UFP).

No PARNA Catimbau é ocasional, aparecendo em beiras de estradas e locais antropizados. Distingue-se por apresentar sépalas externas mucronadas, com margem escariosa e ciliada. É afim a I. vestalii por apresentar sépalas externas glabras, ovais com margem escariosa e múcron revoluto, contudo se difere pela consistência rugosa e a presença de indumento na margem. É facilmente confundida com Ipomoea bahiensis por apresentar folhas sagitadas, contudo não apresenta sépalas externas com rostro subapical.

Jacquemontia Choisy., Mém. Soc. Phys. Genève 6: 476.1834.

Trepadeiras lenhosas ou herbáceas; látex ausente; tricomas estrelados, 3-5-7 armados, simples e glandulares. Folhas inteiras, simples, margem inteira ou serreada, pecioladas, nectários ausentes. Inflorescência axilar; bractéolas presentes ou ausentes. Sépalas iguais ou desiguais; corola inteira, azul, branca ou raro amarela, glabra; estames 5, inclusos, anteras oblongas; ovário globoso, glabro, bilocular, 2 óvulos por lóculo; estilete 1, estigmas 2, ovais-planos ou cilíndricos. Fruto cápsula, deiscente; sementes 4. 
21. Jacquemontia agrestis (Mart. ex Choisy) Meisn. in Mart., Fl. bras. 7: 306. 1869.

Fig. $3 g$

Trepadeiras herbáceas. Ramos pilosos, tricomas simples, estrelados 3-armados e glandulares. Folhas 1,2-2 ×0,9-2,5 cm, cartáceas, margem inteira, pubescentes em ambas faces, cordadas, ápice agudo a apiculado, base cordada; pecíolo 0,3-1 cm compr., pubescente. Monocásio, 2 a 3 flores; pedúnculo 2,5-5,5 cm compr., piloso; bractéolas ca. $2 \mathrm{~mm}$ compr., lineares; pedicelo 5-8 mm compr.; sépalas iguais entre si, ca. $3 \times$ $1 \mathrm{~mm}$, pubescentes a glabrescentes, lanceoladas, ápice acuminado, base arredondada; corola ca. 1 $\mathrm{cm}$ compr., infundibuliforme, glabra, azul com a fauce do tubo vináceo; anteras brancas. Fruto ca. $4 \mathrm{~mm}$ compr., subgloboide.

Material selecionado: Serra de Jerusalém, 19.X.1994, fl. e fr., M .F. Sales 431 (PEUFR). Trilha para Vila do Catimbau, 8.X.2012, fl., G.C. Delgado-Junior \& M. Alves 468 (UFP).

Amplamente distribuída da América do Norte a América do Sul. No Brasil ocorre, principalmente, no Nordeste e no Centro-Oeste em Caatinga, Cerrado e Mata Atlântica (Buril 2013). No PARNA Catimbau, é ocasional, tendo sido encontrada ao longo de estradas. Diferencia-se das demais espécies do gênero, na área de estudo, por ser a única com tricomas glandulares.

\section{Jacquemontia chrysanthera Buril, Brittonia} 63(4): 436. 2011.

Fig. 3h

Trepadeiras lenhosas. Ramos pubescentes, tricomas estrelados, 5(-7)-armados. Folhas 1,5-4 $\times 0,8-2,7 \mathrm{~cm}$, cartáceas, margem inteira, vilosas em ambas faces, ovais, ápice agudo a apiculado, base arredondada; pecíolo 0,6-0,8 cm compr., viloso. Dicásio, ca. 15 flores; pedúnculo 0,7-2 cm compr., viloso; bractéolas ca. $0,5 \mathrm{~cm}$ compr., lineares; pedicelo ca. $3 \mathrm{~mm}$ compr., sépalas desiguais entre si, externas $0,8-1 \times 0,3-0,4 \mathrm{~cm}$, vilosas, lanceoladas, ápice acuminado, base truncada, internas $0,5-0,7 \times 0,2-3 \mathrm{~cm}$, esparsamente vilosas, ovais, ápice acuminado, base arredondada; corola ca. 1,5 cm compr., infundibuliforme, glabra, azul; anteras amarelas. Fruto ca. $5 \mathrm{~mm}$ compr., globoide. Material selecionado: Serra de Jerusalém, 7.VII.2012, fr., G.C. Delgado-Junior \& S.O. Santos 372 (UFP). Trilha para Caverna 12.IX.2012, fl., G.C. Delgado Junior 439 (UFP).

Endêmica da Caatinga, com registros apenas para os estados de Pernambuco e Bahia (Buril 2013). É ocasional no PARNA Catimbau, ocorrendo em afloramentos rochosos e caatinga arbustiva de solo arenoso. É reconhecida facilmente por ser a única espécie do gênero com anteras amarelas.

23. Jacquemontia corymbulosa Benth., Bot. Voy. Sulphur 137. 1844.

Trepadeiras lenhosas. Ramos pubescentes, tricomas estrelados, 3-armados. Folhas 1-4,5 $\times$ $0,7-2,5 \mathrm{~cm}$, cartáceas, margem inteira, vilosas em ambas as faces, cordadas a ovais, ápice acuminado a mucronado, base cordada a arredondada; pecíolo 0,5-0,8 cm compr., viloso. Dicásio, 3 a 21 flores; pedúnculo 1-8 cm compr., viloso; bractéolas ca. $3 \mathrm{~mm}$ compr., lineares; pedicelo $2-5 \mathrm{~mm}$ compr., sépalas desiguais entre si, externas 4-5,5 × 2-2,5 $\mathrm{mm}$, pubescentes, elípticas a lanceoladas, ápice acuminado, base cuneada, intermediária ca. $4 \times 2$ $\mathrm{mm}$, esparsamente pubescente, lanceolada, ápice acuminado, base arredondada, internas ca. $3 \times 1,2$ $\mathrm{mm}$, glabrescentes, lanceoladas, ápice acuminado, base arredondada; corola ca. $1 \mathrm{~cm}$ compr., infundibuliforme, glabra, azul; anteras brancas. Fruto ca. $5 \mathrm{~mm}$ compr., subgloboide.

Material selecionado: Casa de Farinha, 9.VIII.2012, fl. e fr., G.C. Delgado-Junior \& S.O. Santos 411 (UFP). Igrejinha, 8.VIII.2012, fl., G.C. Delgado-Junior \& S.O. Santos 406 (UFP). Trilha para a Cachoeira, 12.IX.2012, fl. e fr., G.C. Delgado Junior \& S.O. Santos 430 (UFP).

Ocorre no Peru, Equador e Brasil, no qual é mais comum na Caatinga do Ceará a Bahia (Buril 2013). É abundante no PARNA Catimbau, sendo distribuída em solos arenosos, pedregosos, afloramentos rochosos e também em áreas degradadas. Distingui-se das demais por apresentar sépalas externas lanceoladas e bractéolas lineares.

24. Jacquemontia ferruginea var. ambigua Meisn., in Mart., Fl. bras. 7: 300. $1869 . \quad$ Fig. 3i-j

Trepadeiras herbáceas. Ramos densamente pubescentes, tricomas estrelados, 3-armados. Folhas 1,5-2,5 × 1-2,7 cm, cartáceas, margem inteira, vilosas em ambas as faces, ovais, ápice acuminado a apiculado, base arredondada; pecíolo 0,5-1 cm compr., viloso. Dicásio, ca. 9 flores; pedúnculo 1-2 cm compr., viloso; bractéolas $0,7-1$ cm compr., lineares; pedicelo 1-2 mm compr.; sépalas desiguais entre si, externas ca. $0,7-1$ $\times 0,4-0,6 \mathrm{~cm}$, pubescentes, rômbicas a ovais, ápice acuminado, base cuneada, intermediária $0,5-6 \times$ $0,2 \mathrm{~cm}$, assimétrica, internas $0,4-0,5 \times 0,2-0,3 \mathrm{~cm}$, tricomas restritos a região mediana, lanceoladas, ápice acuminado, base arredonda; corola ca. $1 \mathrm{~cm}$ compr., infundibuliforme, glabra, azul; anteras brancas. Fruto ca. $4 \mathrm{~mm}$ compr., globoide. 
Material selecionado: Serra de Jerusalém, 12.IX.2012, fl. e fr., G.C. Delgado Junior 448 (UFP). Trilha do Camelo 13.IX.2012, fl., G.C. Delgado Junior 463 (UFP). Trilha para Serra de Jerusalém, 12.IX.2012, fl., G.C. Delgado Junior 440 (UFP).

Endêmica do Brasil, ocorrendo na Mata Atlântica, Caatinga e Cerrado. No PARNA Catimbau, é abundante em afloramentos rochosos e em solos arenosos. Diferencia-se pelas sépalas externas rômbicas a ovais, pubescentes e pedicelo $\leq 2 \mathrm{~mm}$ comprimento.

25. Jacquemontia montana (Moric.) Meisn., in Mart., Fl. bras. 7: 304. 1869.

Trepadeiras herbáceas. Ramos lanosos, tricomas simples. Folhas 2,0-3,5 × 1,5-2,0 cm, cartáceas, margem serreada, lanosas em ambas as faces, ovais, ápice agudo, mucronado, base truncada a ligeiramente cordada; pecíolo 0,5-1,2 cm compr., lanoso. Cimeira capituliforme, ca. 7 flores; pedúnculo 2,5-6 cm compr., lanoso; bractéolas 0,7-1 cm compr., foliáceas; sépalas desiguais entre si, externas ca. $0,8 \times 0,4 \mathrm{~cm}$, pubescentes, ovais, ápice agudo, base cuneada, internas ca. 0,6 × 0,2 $\mathrm{cm}$, oblongas, ápice acuminado, base truncada; corola ca. 1,2 cm compr., campanulada; glabra, amarela; anteras brancas. Fruto não observado.

Material examinado: Estrada para Vila do Catimbau, 1.IX.2013, fl., G.C. Delgado-Junior 712 (UFP). Vila do Catimbau, 11.XI.2003, f1., E.R. Souza 396 (HST).

Endêmica do Brasil e distribuída na Caatinga, Cerrado, e Mata Atlântica, do Ceará ao Rio de Janeiro. No PARNA Catimbau, é rara e há registro apenas ao longo de estradas. É reconhecida por ser a única no gênero com corola amarela e tricomas simples, e por estas características está sendo descrita sob um novo gênero.

26. Jacquemontia nodiflora (Desr.) G. Don., Gen. Hist. 4: 283. 1838.

Trepadeiras lenhosa. Ramos glabrescentes a velutinos, tricomas estrelados 3-armados. Folhas $1-2,5 \times 0,8-2 \mathrm{~cm}$, cartáceas, margem inteira, velutinas em ambas as faces, ovais, ápice agudo a mucronado, base arredondada; pecíolo 0,5-0,8 cm compr., velutino. Dicásio, até 15 flores; pedúnculo 0,5-1,5 cm de compr.; bractéolas ca. $1 \mathrm{~mm}$, lineares; pedicelo 3-6 mm de compr.; sépalas subiguais entre si, externas um pouco menores, $3 \times 2 \mathrm{~mm}$, glabrescentes a pubescentes, rotundas, ápice arredondado, base arredondada; corola ca. $1,5 \mathrm{~cm}$ compr., infundibuliforme, glabra, branca com fauce vinácea; anteras brancas. Fruto ca. 4 mm compr., globoide.
Material examinado: Quixel, 9.VIII.2012, fl., G.C. Delgado Junior 424 (UFP); 9.X.2012, fr., G.C. Delgado Junior 487 (UFP). Sítio Queimada da Onça, VII.2007, fl., O. Cano 702 (IPA).

Ocorre nas Américas, do México ao Brasil, sendo neste distribuída principalmente na Caatinga, além do Cerrado e Mata Atlântica (Buril 2013). No PARNA Catimbau, é ocasional, ocorrendo em locais com solo pedregosos e ambiente úmido. Reconhecida por apresentar sépalas subiguais rotundas e glabrescentes ou pubescentes na base, e bractéolas com $1 \mathrm{~mm}$ compr.

\section{Jacquemontia pentanthos (Jacq.) G. Don.,Gen.} Hist. 4: 283. 1838.

Trepadeiras lenhosas. Ramos glabrescentes a velutinos, tricomas estrelados 3-armados. Folhas 1,5-4 × 1-5 cm, cartáceas, margem inteira, pubescentes em ambas as faces, ovais, ápice acuminado a caudado não mucronado ou agudo a arredondado mucronado, base arredondada a cordada; pecíolo 0,3-2 cm compr., velutino. Dicásio, até 15 flores; pedúnculo 3-14 cm de compr.; bractéolas $0,5-1 \mathrm{~cm}$, lanceoladas ou oblanceoladas; pedicelo 1-4 mm de compr.; sépalas desiguais entre si, externas 3-5 × 2-4 $\mathrm{mm}$, pubescentes, romboides a oblongo-elípticas, ápice agudo a acuminado, base arredondada, intermediária ca. 4x3 $\mathrm{mm}$ assimétrica, pubescente, internas 1,5- 2 × 1-1,5 mm, glabrescentes, margem escariosa, lanceoladas, ápice agudo, base arredondada; corola ca. 1,5 cm compr., infundibuliforme, glabra, branca a azul; anteras brancas. Fruto ca. 4 mm compr., globoide.

Material selecionado: Riachão, 25.VI.2010, fr., $M$. Oliveira \& C.F. Fonseca 4973 (HVASF).

Material adicional: BRASIL. PERNAMBUCO: Ibimirim, 25.I.2011, fl., M. Oliveira 5437 (HVASF).

Amplamente distribuída do México à Argentina(Buril 2013). No Brasil ocorre na Caatinga e Cerrado. Devido à elevada plasticidade pode ser confundida com Jacquemontia corymbulosa. No PARNA, é rara e ocorre em caatinga arbustiva com solos pedregosos, diferencia-se desta última pelas bractéolas lanceoladas a oblanceoladas.

Merremia Dennst. ex Endl., Gen. P1. [Endlicher] Suppl. 1: 1403. 1841.

Trepadeiras lenhosas ou herbáceas, látex presente ou ausente; tricomas simples, glandulares. Folhas compostas, inteiras, margem inteira ou denteada, pecioladas, nectários ausentes. Inflorescência axilar; bractéolas presentes. Sépalas 
iguais ou subiguais; corola inteira, branca, glabra; estames 5, inclusos, anteras oblongas; ovário globoso, bilocular, 2 óvulos por lóculos, glabro; estilete 1; estigmas 2, globosos. Fruto cápsula deiscente; sementes 4 .

28. Merremia aegyptia (L.) Urb., Symb. Antill. 4: 505. 1910.

Trepadeiras lenhosas; látex branco. Ramos hirsutos. Folhas 5-folioladas $2-10 \times 1-6 \mathrm{~cm}$, cartáceas, margem inteira, pubescentes em ambas as faces, folíolos elípticos, ápice acuminado, base cuneada; pecíolo 2-9 cm compr., hirsuto. Dicásio, ca. 8 flores; pedúnculo 8,5-17 cm compr., hirsuto; bractéolas 2-4 mm compr., lanceoladas; pedicelo 1,5-5 cm compr.; sépalas desiguais entre si, externas ca. $1,7 \times 0,8 \mathrm{~cm}$, hirsutas, oblongolanceoladas, ápice atenuado, base truncada, internas ca. $1,1 \times 0,8 \mathrm{~cm}$, glabras, ovais, ápice agudo, base arredondada; corola ca. $3 \mathrm{~cm}$ compr., infundibuliforme, glabra, branca. Fruto $1-1,5 \mathrm{~cm}$ compr., ovoide.

Material selecionado: Estrada para Caiana, 6.VII.06, fl., M. T. Vital et al. 39 (UFP). Sítio Serra Branca, 21.X.2006, fl., E.A. Rocha et al. 1568 (HUESC). Trilha para Vila do Catimbau, 12.IX.2012, fl., G.C. Delgado Junior \& S.O. Santos 426 (UFP).

Material adicional: BRASIL. PERNAMBUCO: Trindade, BR 316, 26.IV.1985, fr., F. Gallindo 7373 (PEUFR).

Pantropical (Fosberg \& Sachet 1977), no Brasil ocorre do Norte ao Sudeste (Bianchini \& Ferreira 2013). No PARNA Catimbau, é rara, sendo encontrada em áreas antropizadas, diferencia-se das demais pelos ramos, pecíolo, pedúnculo e sépalas hirsutos e dourados quando secos.

29. Merremia cissoides (Lam.) Hallier f., Bot. Jahrb. Syst. 16: 552. 1893.

Trepadeiras herbáceas; látex não observado. Ramos pubescentes, tricomas glandulares e simples. Folhas 5-(6)-folioladas, 1,5-3,5 × 0,5-1,5 cm, cartáceas, margem denteada, tricomas glandulares restritos à margem, folíolos elípticos, ápice agudo, mucronado, base cuneada; pecíolo $0,5-1,5 \mathrm{~cm}$ compr.. Flor isolada ou em monocásio, ca. 4 flores; pedúnculo 1-3,5 cm compr., pubescente; bractéolas 5-9 mm compr., lineares; pedicelo 5-7 mm compr.; sépalas subiguais entre si, externas ca. 1,4 × 0,5 $\mathrm{cm}$, puberulentas, romboides a ovais, ápice longo atenuado, base cuneada, internas ca. 1,3 × 0,3 $\mathrm{cm}$, ovais, ápice longo atenuado glabrescente a puberulento, base cuneada; corola ca. $3 \mathrm{~cm}$ compr., infundibuliforme, glabra, branca. Fruto ca. $1 \mathrm{~cm}$ compr., globoide.

Materiais selecionados: Fazenda Laranjeiras, 20.V.1995, fl., K. Andrade et al. 55 (PEUFR). Vale do Catimbau, 12.III.2006, fl., M.T. Vital 23 (UFP).

Material adicional: BRASIL. PERNAMBUCO: Bezerros, Distrito de Sapucarama, Pedra Antônio Bezerra, 16.III.06, fr., M.T. Buril et al. 24 (UFP).

Neotropical, ocorrendo desde o México à Argentina (O'Donell 1941) e presente em todo território brasileiro (Bianchini \& Ferreira 2013). No PARNA Catimbau é rara, sendo encontrada em áreas antropizadas. É facilmente reconhecida pelos ramos com tricomas glandulares e folhas com margem denteadas.

30. Turbina cordata (Choisy) D.F.Austin \& Staples, J. Arnold Arbor. 64: 488. 1983.

Fig. 3k-m

Trepadeiras lenhosas; látex branco. Ramos vilosos, tricomas simples. Folhas inteiras, 5-8 x 3,5-7,5 cm, cartáceas, margem inteira, face adaxial glabrescente, com tricomas restritos às nervuras, face abaxial densamente vilosa, cordadas, ápice mucronado, base cordada; pecíolo 3-6,5 $\mathrm{cm}$ compr., densamente viloso. Dicásio, ca. 12 flores, axilar; pedúnculo $6-10 \mathrm{~cm}$ de compr., viloso a esparsamente viloso; bractéolas ausentes, pedicelo 0,5-2 cm compr.; sépalas desiguais entre si, externas $1,5 \times 0,9-1,2 \mathrm{~cm}$, pubescentes, rotundas a ovais, ápice arredondado, base truncada, internas 1,6-1,8 x 1-1,2 cm, pubescentes, rotundas a obovais, ápice arredondado, base truncada a cuneada; corola inteira, infundibuliforme, ca. $5 \mathrm{~cm}$ compr., vilosa sobre a nervura mesopétala, rosa; estames inclusos; ovário ovoide, bilocular, 2 óvulos por lóculo, glabro; estilete 1, filiforme; estigmas 2 globosos. Cápsula indeiscente ca. $2 \mathrm{~cm}$ compr., elipsoides; semente 1, glabrescente.

Material selecionado: Alcobaça, 10.X.2012, fl., G.C. Delgado Junior et al. 503 (UFP); Trilha das Torres, 18.XI.2008, fl., R. Pereira 2844 (IPA).

Material adicional: BRASIL. PARAÍBA: São José dos Cordeiros, RPPN Fazenda Almas, 18.VIII. 2010, fr., G.C. Delgado-Junior 210 (JPB).

Amplamente distribuída no Brasil, principalmente na Caatinga e Cerrado (Bianchini \& Ferreira 2013) e também com registros no Peru (Austin \& Staples 1991). No PARNA Catimbau, é rara e encontrada em caatingas de solos arenosos e afloramentos rochosos. É confundida com a Ipomoea brasiliana e I. subincana, mas diferenciase a partir de características já discutidas nos comentários dessas espécies. 


\section{Agradecimentos}

Os autores agradecem o apoio financeiro concedido pela CAPES e pelo CNPq.

\section{Referências}

Austin, D.F. \& Cavalcante, P.B. 1982. Convolvuláceas da Amazônia. Publicações Avulsas do Museu Goeldi 36: $3-134$

Austin, D.F. \& Staples, G.W. 1991. A revision of the neotropical species of Turbina Raf. (Convolvulaceae). Bulletin of the Torrey Botanical Club 118: 265-280.

Austin, D.F. \& Huáman, Z. 1996. A synopsis of Ipomoea (Convolvulaceae) in the Americas. Taxon 45: 3-38.

Austin, D.F. 2004. Convolvulaceae. In: Smith, N.P.; Mori, S.A.; Henderson, A.; Stevenson, D. W. \& Heald, S.V. (eds.). Flowering plants of the Neotropics. New York Botanical Garden, Princeton University Press, Princeton. Pp. 113-115.

Barbosa, M.R.V.; Lima, I.B.; Cunha, J.P.; Agra, M.F. \& Thomas, W.W. 2007. Vegetação e flora no Cariri Paraibano. Oecologia Brasiliensis 11: 313-322.

Bianchini, R.S. 1998. Ipomoea no Sudeste do Brasil. Tese de Doutorado. Instituto de Botânica, São Paulo. 476p.

Bianchini, R.S. 2001. Convolvulaceae. In: Cavalcanti, T.B. \& Ramos, A.E. (eds.). Flora do Distrito Federal, Brasil. Flora do Distrito Federal, Brasil. Embrapa Cenargen, Brasília. Pp. 164-169.

Bianchini, R.S. \& Ferreira, P.P.A. 2013. Convolvulaceae. In: Lista de espécies da flora do Brasil. Disponível em <http://reflora.jbrj.gov.br/jabot/listaBrasil/ ConsultaPublicaUC/ConsultaPublicaUC.do $>$. Acesso em 10 Mai 2013.

Bianchini, R.S. \& Pirani, J.R. 1997. Flora da Serra do Cipó, Minas Gerais: Convolvulaceae. Boletim de Botânica da Universidade de São Paulo 16: 125-149.

Buril, M.T. \& Alves, M. 2011. A new species of Jacquemontia (Convolvulaceae) from Northeastern Brazil. Brittonia 63: 436-441.

Buril, M.T. 2013. Sistemática e Filogenia de Jacquemontia (Choisy) Convolvulaceae. Tese de Doutorado. Universidade Federal de Pernambuco, Recife. 322p.

Durigon, J.; Canto-Dorow, T. S.; \& Eisinger, S. M. 2009. Composição florística de trepadeiras ocorrentes em bordas de fragmentos de floresta estacional, Santa Maria, Rio Grande do Sul, Brasil. Rodriguésia 60: 415-422.

Ferreira, P.P.A. \& Miotto, S.T.S. 2009. Sinopse das espécies de Ipomoea L. (Convolvulaceae) ocorrentes no Rio Grande do Sul, Brasil. Revista Brasileira de Biociências 7: 440-453.

Ferreira, P.P.A. \& Miotto, S.T.S 2013. O gênero Merremia (Convolvulaceae) na Região do Sul do Brasil. Rodriguésia 64: 635-646.
Fosberg, R.F. \& Sachet, M.H. 1977. Convolvulaceae. In: Fosberg, R.F. (ed.). Flora of Micronesia. Vol. 3. Smithsonian Institution. Pp. 1-34.

Junqueira, M.E.R. \& Bianchini, R.S. 2006. O gênero Evolvulus L. (Convolvulaceae) no município de Morro do Chapéu, BA, Brasil. Acta Botanica Brasilica 20: 157-172.

Harris, J.G. \& Harris M.W. 2000. Plant identification terminology: an illustrated glossary. Spring Lake Publishing, Spring Lake. 197p.

Meisner, C.F. 1869. Convolvulaceae. In: Martius, C.P.F. \& Eichler, A.G. (eds.). Flora brasiliensis. Vol. 7. Pp. 199-370.

Melo, J.I.M. 2012. Flora do Parque Nacional do Catimbau, Pernambuco, Brasil: Boraginaceae sensu lato. Biotemas 25: 109-120.

Mori, S.A.; Mattos-Silva, L.A.; Lisboa, G. \& Coradin, L. 1985. Manual de manejo do herbário fanerogâmico. Centro de Pesquisas do Cacau, Ilhéus. 95p.

Moura, A.L.O. 2010. Convolvulaceae em remanescentes de Floresta Ombrófila Densa do estado do Rio de Janeiro. Dissertação de Mestrado. Instituto de Pesquisas do Jardim Botânico do Rio de Janeiro, Rio de Janeiro.

O’Donell, C.A. 1941. Revisión de las especies americanas de Merremia. Lilloa 6: 467-554.

Ooststroom, S.J.V. 1934. A monograph of the genus Evolvulus. Mededeelingen van het botanisch museum en herbarium van de rijks universiteit te Utrecht 14: 1-267.

Robertson, K.R.1982. Odonellia, a new genus of Convolvulaceae from Tropical America. Brittonia 34: 417-423.

Rodal, M.J.L.; Andrade, K.V.S.; Sales, M.F. \& Gomes, A.P.S. 1998. Fitossociologia do componente lenhoso de um refúgio vegetacional no município de Buíque, Pernambuco. Revista Brasileira de Biologia 58: 517-526.

Rhui-cheng, F. \& Staples, G. 1995. Convolvulace. In: Wu, C.Y.; Hong, De-Y. \& Raven, P.H. (eds.). Flora of China. Science Press, Missouri Botanical Garden Press, Beijing, St. Louis. 16: 271-325.

SADMET/INMET. Seção de Armazenamento de Dados Meteorológicos/Instituto de Meteorologia. 2013. Disponível em <http://www.inmet.gov.br/html/ central servicos/combo produtos.html>. Acesso em 24 Mai 2013.

Sampaio, E.V.S.B; Giulietti, A.M.; Virgínio, J. \& Gamarra-Rojas, C. 2002. Vegetação e flora da Caatinga. Associação de Plantas do Nordeste (APNE), Centro Nordestino de Informações sobre Plantas (CNIP), Recife. Pp. 49-90.

Siqueira-Filho, J.A; Conceição, A.A; Rapini, A; Coelho, A.O.P; Zuntini, A. R; Joffily, A; Vieira, A.O.S; Prata, A.P.N; Machado, A.F.P; Alves-Araújo, A.G; Melo, A. L.. Amorim, A.M.A; Fontana, A.P; Moreira, A.D.R; Lima, C.T; Proença, C.E.B; Luz, C.L; 
Kameyama, C.S; Caires, C.S; Bove, C.P; Mynssen, C.M; Sá, C.F.C; Melo, E; Souza, E.B; Leme, E.M.C; Firetti-Leggieri, F; Salimera, F.R.G; França, F; Raine, J.E.Q; Faria, J.E.Q; Maciel, J.R; Lopes, J.C; Braga, J.M.A; Stehmann, J.R; Jardim, J.G; Pereira, J.F; Pastore, J.F.B; Valls, J.F.M; De Melo, J.I.M; Pirani, J.R; Silva, J.A; Paula-Souza, J.; Cardoso, L.J.T; Matias, L.Q; Lohmann, L.G; Queiroz, L.P; Oliveira, M.A; Sobral, M.E.G; Silva, M.J; Meiado, M.V; Coelho, M.A.N; Costa e Silva, M.B; Mamede, M.C.H; Lucena, M.F.; Pessoa, M.C.R; Loiola, M.I.B; Arbo, M.M; Barbosa, M.R.V; Marchioretto, M.S; Buril, M.T; Bovini, M.G; Bueno, N.C; Fiaschi, P; Borges, R.A.X; Forzza, R.C; Sebastiani, R; Mello-Silva, R; Couto, R.S; Lima, R.B; Pereira, R.C.A; Marquete, R; Barreto, R.C; Xavier, S.RS; Profice, S.R; Cavalcanti, T.B; Silva, T.R.S; Pott, V.J; Klein, V.L.G \& Souza, V.C. 2012. Flora das caatingas do rio São Francisco. In: Siqueira-Filho, J. A. A flora das Caatingas do rio São Francisco: história natural e conservação. Andrea Jakobsson, Rio de Janeiro. Pp. 445-542.
Staples, G.W. 2012. Convolvulaceae Unlimited. Disponível em $<$ http://convolvulaceae.myspecies. info/>. Acesso em 10 Mai 2013.

Staples, G.W. \& Brummitt, R.K. 2007. Convolvulaceae. In: Heywood, V.H.; Brummitt, R.K.; Culham, A. \& Seberg, O. (eds.). Flowering plant families of the world. Royal Botanic Gardens, Kew. Pp. 108-110.

Stearn, W.T. 2004. Botanical latin. 4 ed. David \& Charles Publishers, Newton Abbot. 546p.

Stefanovic, S.; Krueger, L. \& Olmstead, R.G. 2002. Monophyly of the Convolvulaceae and circumscription of their major lineages based on DNA sequences of multiple chloroplast loci. American Journal of Botany 89: 1510-1522.

Vital, M.T.B.; Santos, F.A.R. \& Alves, M. 2008. Diversidade palinológica das Convolvulaceae no Parque Nacional do Catimbau, Buíque-PE, Brasil. Acta Botanica Brasilica 22: 1163-1171.

Vital, M.T. 2009. Convolvulaceae. In: Alves, M.; Araújo, M.F.; Maciel, J.R. \& Martins, S. (eds.). Flora de Mirandiba. Associação de Plantas do Nordeste (APNE), Recife. Pp. 121-134.

\section{Lista de exsicatas}

Alves, J.L.H. UFP 33776 (8). Andrade, K. 34 (21), 55 (29). Cano, O. 739 (2), 818 (3), 755(4), 792 (4), 801 (4), 795 (11), 17 (15), 794 (18), 835 (19), 702 (26). Costa, A.C.G. 19 (15). Delgado-Junior, G.C. 662 (2), 643 (2), 594 (3), 663 (4), 657 (5), 624 (5), 623 (6), 642 (7), 453 (7), 695 (10) 297 (11), 690 (12), 404 (13), 344 (13), 391 (13), 347 (13), 359 (13), 368 (13), 691 (14), 619 (15), 318 (15), 338 (15), 358 (15), 364 (17), 346 (17), 296 (18), 329 (18), 308 (18), 722 (19), 721 (20), 468 (21), 372 (22), 457 (22), 439 (22), 411 (23), 406 (23), 418 (23), 430 (23), 448 (24), 463 (24), 440 (24), 712 (25), 424 (26), 487 (26), 426 (28), 503 (30). Ducke 2544 (16). Figueiredo, L.S. 109 (7), 111 (11), 108 (13). Frazão, A.M. HST 6807 (6). Freire, E. 26 (8). Gallindo, F. PEUFR 7373 (28). Gomes, P. 68 (15), 69 (18), 70 (18). Lacerda, A.C. HST 10114 (25), HST 7195 (6). Leite, M.S. 329 (18). Lemos, J.R. 84 (7), 84 (18). Machado, I.C. UFP 31787 (2) Miranda, A.M. 4469 (2), 5670 (3), HST 16070 (3), 1836 (4), 4474 (4), 5669 (4), HST 16071 (4), 5710 (11), 2688 (6), 1828 (18), 2485 (28), Oliveira, C.R.S. 315 (7), 234 (18). Oliveira, M. 2202 (10). Pereira, R. 1144 (3), 2731(3), 2729 (7), 2833 (9), 2706 (10), 2725 (11), 2777 (12), 2724 (12), 2702 (16), 2844 (30). Pick, R.A. 227 (3), 275 (4) 56 (6), 241 (6), 263 (17), 212 (18), 279 (20). 64 (22), 314 (23), 270 (23) 317 (24). Pinheiro, K. 881 (12). Praciano, T. PEUFR 17921 (9). Rocha, E.A. 1568 (28). Rodal, M.J.N. 533(7), 532 (11). Rodrigues, A. 19 (2), 17 (4), 18 (13), 20 (18), 57 (18). Sales, M.F. 431 (21). Schlindwein, C. 31 (5). Silva, A.G. 1665 (2), 1376 (4), 1664(13). Silva, J.S. 215 (15). Souza, E.R. 396 (25). Vital, M.T. 21 (1), 15 (2), 16 (3), 19 (3), 35 (3), 36 (4), 40 (6), 43 (6), 41 (12), 17 (15), 20 (18), 22 (18), 42 (20), 45 (23), 38 (26) 44 (28), 39 (28) 23 (29), 24 (29), 37 (27). 